Original Research Paper

\title{
Effects of Light Exposure and Nitrogen Source on the Production of Oil from Freshwater and Marine Water Microalgae
}

\author{
Mariam Al Hattab and Abdel Ghaly \\ Department of Process Engineering and Applied Science, Dalhousie University, Halifax, Nova Scotia, Canada
}

Article history

Received: 20-08-2014

Revised: $30-08-2014$

Accepted: 20-10-2014

Corresponding Author:

Abdel Ghaly,

Department of Process

Engineering and Applied

Sciences, Dalhousie University,

Halifax, Nova Scotia, Canada

Email: abdel.ghaly@dal.ca

Tel: (902) 494-6014

\begin{abstract}
The biomass yield and oil content of Chlorella saccharophila (freshwater) and Tetraselmis suecica (marine) microalgae were investigated using various nitrogen source (ammonium nitrate, ammonium phosphate, ammonium sulfate and combination of nutrients) at various light durations (9,16 and $24 \mathrm{~h}$ ). $\mathrm{NaHCO}_{3}$ was used as the carbon source. The nitrogen concentration, temperature and $\mathrm{pH}$ were maintained at $70 \mathrm{mg} / \mathrm{L}, 22^{\circ} \mathrm{C}$ and 8.5 , respectively. The results indicated that $T$. suecica produced higher cell yield compared to the $C$. saccharophila under all levels of parameters tested. Light exposure of $24 \mathrm{~h}$ produced the highest biomass yield. However, the difference in cell yields between light duration of 16 and $24 \mathrm{~h}$ was not significant. The combination of nutrients resulted in the highest growth for both species of microalgae. However, high growth did not necessarily result in high oil yield. The oil content was much higher for C. saccharophila than $T$. suecica. Varying light duration had no direct effect on oil yield. The nutrient type significantly influenced the production of oil. $C$. saccharophila produced the highest oil yield using ammonium phosphate while $T$. suecica achieved the highest oil yield using ammonium nitrate. The results indicated that high algal growth does not necessarily result in high oil yield. Both, the generation of new cells and storage of oil require energy. When the cells used energy for generation of new cells they store less oil. Thus, growing C. saccharophila using the combination of nutrients at $16 \mathrm{~h}$ light exposure would be the optimal growth conditions for producing oil for biodiesel production.
\end{abstract}

Keywords: Microalgae, Freshwater, Marine, $\mathrm{NaHCO}_{3}, \mathrm{CO}_{2}$, Nitrogen Source, Light, Biomass, Oil, Extraction

\section{Introduction}

The increase in the annual global energy consumption over the past century has relied heavily on fossil fuels (oil, coal and natural gas) for powering up cars, farms, factories and for production of electricity (Areva, 2011). The world consumption of crude oil, coal and natural gas in 2011 was 87.4 million barrels/day, 8 144 million short tons/day (4.64 billion barrels of oil/day) and 3368 billion $\mathrm{m}^{3}$ (2 118 barrels of oil/day), respectively (Barrientos and Soria, 2011). Fossil fuel burning has accelerated Carbon Dioxide $\left(\mathrm{CO}_{2}\right)$ emissions on a global scale from $1.1 \%$ per year in 1990 to more than $2.6 \%$ per year in 2010 (Adams, 2013). This has contributed to global warming which impacted all living organisms (Root et al., 2003). An increase in the earth's temperature has been attributed to a decline in the Adelilie penguins species, melting of glaciers, increased sea level and increased precipitation resulting in floods (Forcada et al., 2006). In Canada, forest fires, floods, insect infestations and drought have all been attributed to global warming (Epstein, 2000).

The environmental concerns associated with greenhouse gas emissions emphasise the need for alternative energy sources that are more environmentally friendly. Various types of biomass can be used as renewable energy sources that offer immediate prospects of producing liquid fuels such as biodiesel and bioethanol which can be used as substitutes for petroleum products (Singh and $\mathrm{Gu}$, 
2010). Using biofuels, offer the benefits of greater energy security, foreign exchange savings and reduced environmental effects (Balat, 2009; Kan, 2009; Yenikaya et al., 2009). Biomass feedstocks for energy production include food waste, municipal waste, agricultural waste, edible and nonedible oilseeds, aquatic plants and algae.

Microalgae, which are abundant in nature, can be used as an alternate fuel source because of their high growth rate and their ability to produce lipids that can be used for the production of biodiesel (Chisti, 2007; $\mathrm{Hu}$ et al., 2008; Song et al., 2008). The majority of lipids produced by microalgae have a low degree of unsaturation, making them a good energy source for replacement of fossil fuels (Singh and Gu, 2010). Microalgae are photosynthetic microorganisms capable of surviving in marine and fresh water environments, tend to have a much higher oil content than vegetable plants, can produce and store large amounts of oil without the production and release of harmful wastes into the environment, are extremely resilient and often unaffected by fluctuations in the environment and utilize the carbon dioxide for their growth, thus help reduce greenhouse gas emissions (Demirbas, 2010; Singh et al., 2010; Wahlen et al., 2011; Pokoo-Aikins et al., 2010; Demirbas et al., 2011).

Biodiesel, as a liquid fuel, can be produced by the transesterification of oil (triacylglycerols) extracted from microalgae by the addition of methanol and the use of a catalyst such as acid, alkali or enzyme (Leung et al., 2010; Demirbas and Demirbas, 2011; Wahlen et al., 2011; Demirbas, 2005; Chen et al., 2009). The waste generated from the microalgal biomass can be further utilized to produce other biofuels such as methane and ethanol via fermentation or used as animal feed and organic fertilizer (Chen et al., 2009; Demirbas, 2010; Demirbas, 2011). Biodiesel from microalgae generates the same amount of energy as that generated from petroleum diesel without the release of harsh compounds (NOx, SOx and hydrocarbons) into the atmosphere, it is biodegradable and nontoxic and it can be utilized in existing diesel engines without any modifications (Ulusoy et al., 2004; Demirbas, 2005; Kalam and Masjuki, 2005; Singh and $\mathrm{Gu}, 2010$ ).

The main objectives of this study were: (a) to select two strains of microalgae, one freshwater and one marine microalgae based on growth and oil production, (b) to evaluate the effect of light duration (9,16 and $24 \mathrm{~h}$ ) and nutrients type (ammonium nitrate, ammonium phosphate, ammonium sulfate and a mix of all three), while maintaining the nitrogen concentration at $70 \mathrm{mg} / \mathrm{L}$ and using $\mathrm{NaHCO}_{3}$ as a carbon source, on the microalga biomass yield and oil content of these species.

\section{Materials and Methods}

\section{Experimental Apparatus}

A fully automated multiple open pond system (Fig. 1) consisted of a frame, 18 open pond units, a cooling unit, a lighting unit, a supernatant collection unit and control unit was used in this study.

The frame $(244 \mathrm{~cm}$ in width $\times 41 \mathrm{~cm}$ in depth $\times 283$ $\mathrm{cm}$ in height) consisted of three shelves ( $76 \mathrm{~cm}$ apart) and housed the open pond, light, cooling, water collection and control units. Each shelf was divided vertically into two sides by a $1.2 \mathrm{~cm}$ thick plywood sheet to provide a better control of light and feed.

The open pond unit consisted of six ponds, each was made of galvanized steel and was divided into three compartments (each was $38 \mathrm{~cm}$ in length $\times 38 \mathrm{~cm}$ in width $\times 12.5 \mathrm{~cm}$ in depth and can holds up to $18 \mathrm{~L}$ ).

The lighting unit provided 430 hectolux of illumination per shelf $\left(480 \mu \mathrm{mol} \mathrm{m} \mathrm{m}^{-2} \mathrm{~s}^{-1}\right)$ using a mixture of fluorescent and incandescent lamps (six 40 $\mathrm{W}$ cool white fluorescent lamps $122 \mathrm{~cm}$ in length and four $100 \mathrm{~W}$ incandescent bulbs) mounted on each shelf, that sit $100 \mathrm{~cm}$ away from the ponds.

A cooling unit was designed to continuously remove the heat produced by the lamps to avoid heating of the algae media on the upper and middle shelves. A $5 \mathrm{~cm}$ diameter PVC pipe (having $6 \mathrm{~mm}$ diameter holes spaced $6 \mathrm{~cm}$ apart and facing out) was placed under the backside of the ponds. Two metal blocks placed under each pond provided a $5 \mathrm{~cm}$ space between the pond and the lighting system of the shelf below it. A $5 \mathrm{~cm}$ diameter PVC pipe was attached vertically to the left side of the frame and acted as a manifold through which air was blown by means of a motor driven fan (Model AK4L143A Type 821, Franklin Electric, Bluffton, Indiana).

The supernatant from each tray was collected in a separate container $(2.7 \mathrm{~L}$ each) located at the bottom of the system. The outlets were connected to plastic tubes of $1 \mathrm{~cm}$ outside diameter, which were passed through a specially designed solenoid valve.

A computer was used to operate and control the various components of the open pond system and record the various measurements. The light intensity was measured using a Quantum Sensor (SQ-316 Series, Apogee, Logan, Utah). The $\mathrm{pH}$ was measured using $\mathrm{pH}$ electrodes (EW-59001-65, Cole Parmer, Montreal, Quebec). The temperature was measured using thermocouples (WD-08541-12, Nova-Tech International, Houston, Texas). A basic computer program (BASIC Stamp Editor $\mathrm{v}$ 2.5) allowed the configuration of the operating frequency and duration 
of the light, aeration unit and collection system. The computer was connected to a data coordinator (cDAQ9178, National Instruments, Vaudreuil-Dorion, Quebec) which had 24 digital output ports and 24 digital input ports. The digital output ports were connected to electronic circuits which were responsible for the lighting, cooling and collection systems.

\section{Microalgae}

Eight freshwater microalgae (Botrycoccus brauni,
Chlorella protothecides, Chlorella pyrenoidsa, Chlorella saccharophila, Chlorella sorokiniana, Chlorella vulgaris, Chlorococcum sp. and Scenedesmus obliqus) and six marine (Chaetoceros muelleri, Isochrysis sp., Nannochloropsis sp., Pavlova salina, Phaeodactylum tricornutum, Skeletonema costatum and Tetraselmis suecica) microalgae species were selected based on their ability to yield high biomass and store lipids (Table 1 ). The relationship between lipid content $(\%)$ and biomass yield $(\mathrm{g} / \mathrm{L})$ is

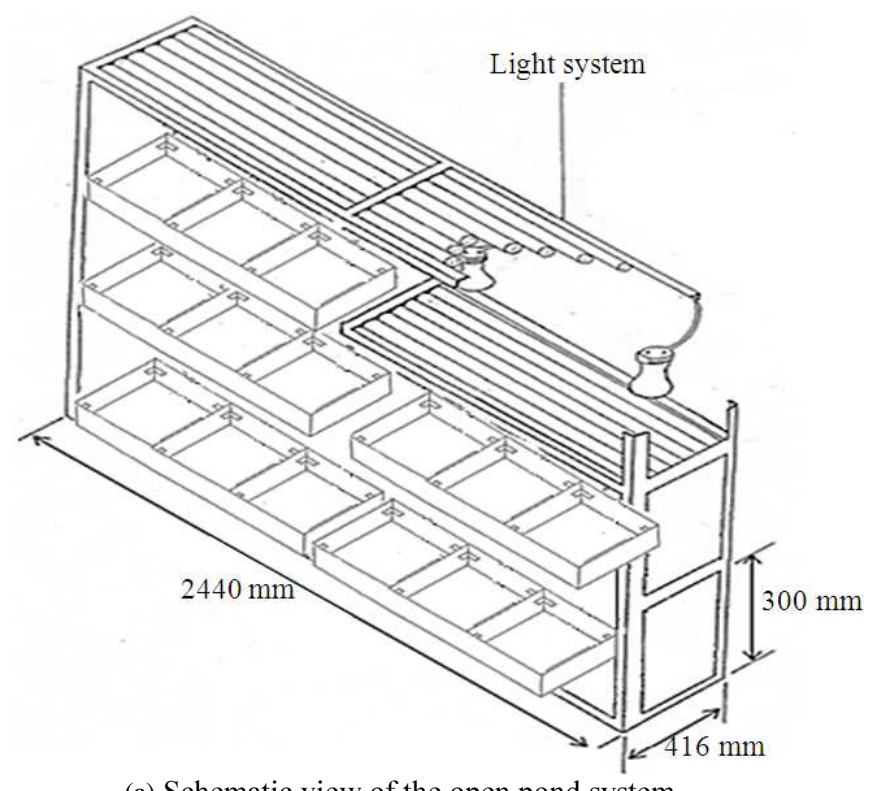

(a) Schematic view of the open pond system

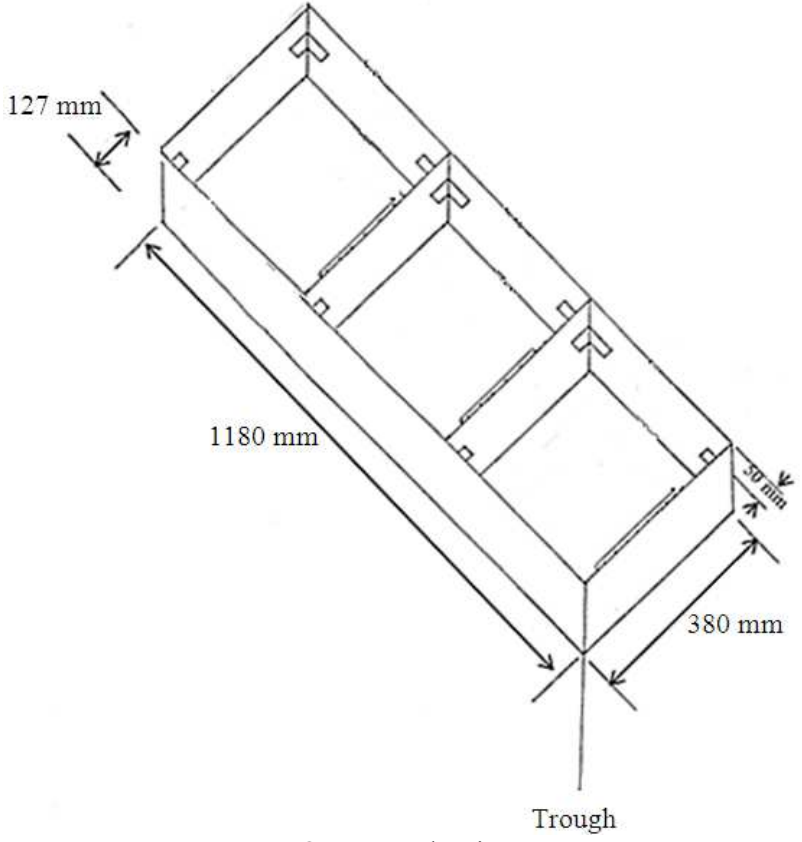

(b) Open pond unit

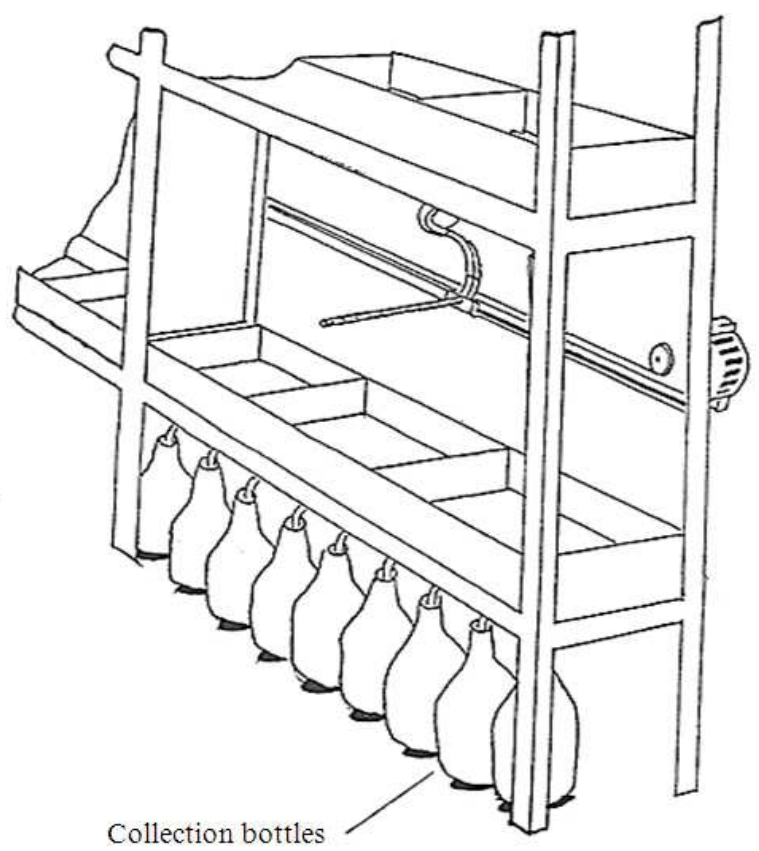

(c) Collection unit

Fig. 1. Experimental apparatus 
Table 1. Lipid contents, temperature and $\mathrm{pH}$ of freshwater and marine water microalgae species

\begin{tabular}{|c|c|c|c|c|c|c|c|}
\hline Species & $\begin{array}{l}\text { Biomass } \\
(\mathrm{g} / \mathrm{L})\end{array}$ & $\begin{array}{l}\text { Lipid } \\
\text { Content } \\
(\%)\end{array}$ & $\begin{array}{l}\text { Lipid } \\
\text { Yield } \\
(\mathrm{g} / \mathrm{L}) \\
\end{array}$ & $\begin{array}{l}\text { Lipid } \\
\text { Productivity } \\
(\mathrm{mg} / \mathrm{L} / \mathrm{d})\end{array}$ & $\begin{array}{l}\text { Temp. } \\
\left({ }^{\circ} \mathrm{C}\right)\end{array}$ & $\mathrm{pH}$ & Reference \\
\hline \multicolumn{8}{|l|}{ Freshwater } \\
\hline Botryococcus brauni & 1.84 & 25.20 & 0.46 & 5.51 & 20 & 7.6 & Velichkova et al. (2012) \\
\hline Chlorella protothecides & 1.32 & 31.23 & 0.41 & 39.60 & 25 & 6.0 & $\begin{array}{l}\text { Liu et al. (2011); } \\
\text { Shi et al. }(2006)\end{array}$ \\
\hline Chlorella pyrenoidosa & 2.84 & 38.95 & 1.11 & 107.90 & $25-30$ & 7.4 & Liu et al. (2011) \\
\hline Chlorella saccharophila & 3.88 & 45.46 & 1.76 & 153.38 & $20-24$ & $7.5-9$ & Liu et al. (2011) \\
\hline Chlorella sorokiniana & 3.22 & 19.30 & 0.62 & 44.70 & 30 & $7-8$ & $\begin{array}{l}\text { Rodolfi et al. (2009); } \\
\text { Moronta et al. (2006) }\end{array}$ \\
\hline Chlorella vulgaris & 1.01 & 27.66 & 0.28 & 27.61 & $25-30$ & 7.0 & Liu et al. (2011) \\
\hline Chlorococcum sp. & 3.92 & 19.30 & 0.76 & 53.70 & $25-30$ & $8-8.5$ & Rodolfi et al. (2009) \\
\hline $\begin{array}{l}\text { Scenedesmus obliqus } \\
\text { Marine }\end{array}$ & 4.36 & 38.98 & 1.70 & 117.00 & $20-30$ & 8.0 & Liu et al. (2011) \\
\hline Chaetoceros muelleri & 0.98 & 33.60 & 0.33 & 21.80 & $20-30$ & 8.0 & Rodolfi et al. (2009) \\
\hline Isochrysis sp. & 2.38 & 22.40 & 0.53 & 37.70 & 25 & 8.0 & $\begin{array}{l}\text { Rodolfi et al. (2009); } \\
\text { Liu and Lin (2001) }\end{array}$ \\
\hline Nannochloropsis sp. & 2.80 & 24.40 & 0.68 & 48.20 & $20-25$ & 8.4 & $\begin{array}{l}\text { Rodolfi et al. (2009); } \\
\text { Spolaore } \text { et al. (2006) }\end{array}$ \\
\hline Phaeodactylum tricornutum & 3.36 & 18.70 & 0.63 & 44.80 & $25-30$ & 8.0 & Okauchi and Tokuda (2003) \\
\hline Skeletonema costatum & 1.12 & 21.10 & 0.24 & 17.40 & 25 & 7.4 & $\begin{array}{l}\text { Rodolfi et al. (2009); } \\
\text { Yan et al. (2002) }\end{array}$ \\
\hline Tetraselmis suecica & 4.48 & 23.00 & 1.03 & 36.40 & $18-24$ & $7-9$ & Rodolfi et al. (2009) \\
\hline
\end{tabular}

illustrated in Fig. 2 and 3 for the freshwater and marine microalgae species, respectively. The selection of the microalgae was based on the oil yield $(\mathrm{g} / \mathrm{L})$. The oil yield was calculated by determining the portion of the weighted biomass that corresponds to the lipid content, by multiplying the percentage that is made up of the lipids.

The freshwater strain Chlorella saccharophila was selected for the study because of its high lipid content $(45 \%)$. This strain is capable of achieving a biomass yield of $3.88 \mathrm{~g} / \mathrm{L}$, which is not the highest among the freshwater species, but can however be offset by the fact that it achieves the highest lipid content. This results in a lipid yield of $1.75 \mathrm{~g} / \mathrm{L}$. The highest biomass yielding algae Scenedesmus obliqus of $4.34 \mathrm{~g} / \mathrm{L}$ only achieves a lipid content of $38 \%$, which intern results in a lipid yield of $1.69 \mathrm{~g} / \mathrm{L}$. In addition this species has the highest lipid productivity when compared to the other freshwater species. However, this was not the basis for selection since productivity can change depending on the length of growth and the phase of growth in which the productivity was measured. Chlorella saccharophila is a green unicellular microalga belonging to the Chlorella genus (Lewis, 1997). The cells have an average size of $7.3 \mu \mathrm{m}$ (Bock et al., 2011). The cells contain a single chloroplast enclosed in a spherical or subspherical form (Fig. 4a). These cells reproduce asexually through production of nonmotile autospores (John et al., 2002). This species is able to use glucose (Singh et al., 2013), bicarbonate and carbon dioxide as the carbon source for growth (Matsuda and Colmen, 1996). The optimal temperature and $\mathrm{pH}$ for growth are $20-24^{\circ} \mathrm{C}$ and $7.5-8$, respectively.

The marine microalgae strain Tetraselmis suecica was selected for the study because of its high biomass yield of $4.48 \mathrm{~g} / \mathrm{L}$ and comparatively high lipid content (23\%). This species did not achieve the highest lipid content among the other species but can, however, be offset by the fact that it achieves the highest biomass yield. This results in a lipid yield of $1.03 \mathrm{~g} / \mathrm{L}$, while the Chaetoceros muelleri which has the highest lipid content of $34 \%$ and a biomass yield of $0.98 \mathrm{~g} / \mathrm{L}$ results in a lipid yield of $0.33 \mathrm{~g} / \mathrm{L}$. The productivity value for this species is not the highest when comparing it to the other marine microalgae species. The productivity can change depending on the length of growth and the growth phase in which the productivity was measured. It is for this reason that the selection of the species was based on the lipid yield (g/L). Tetraselmis suecica grows as single cells. They are motile and can be compressed or curved (Fig. 4b), but they are never twisted (Acuna and Kiefer, 2000). The cells are spherical or elliptic with a length of $35 \mu \mathrm{m}$ and a width of $14 \mu \mathrm{m}$. This species is able to use both sodium bicarbonate (White et al., 2012) and carbon dioxide (de Castro Araujo and Garcia, 2005) as the carbon source for growth. The optimal temperature and $\mathrm{pH}$ for growth are $18-24^{\circ} \mathrm{C}$ and $7-9$, respectively (Lavens and Sorgeloos, 1996). 


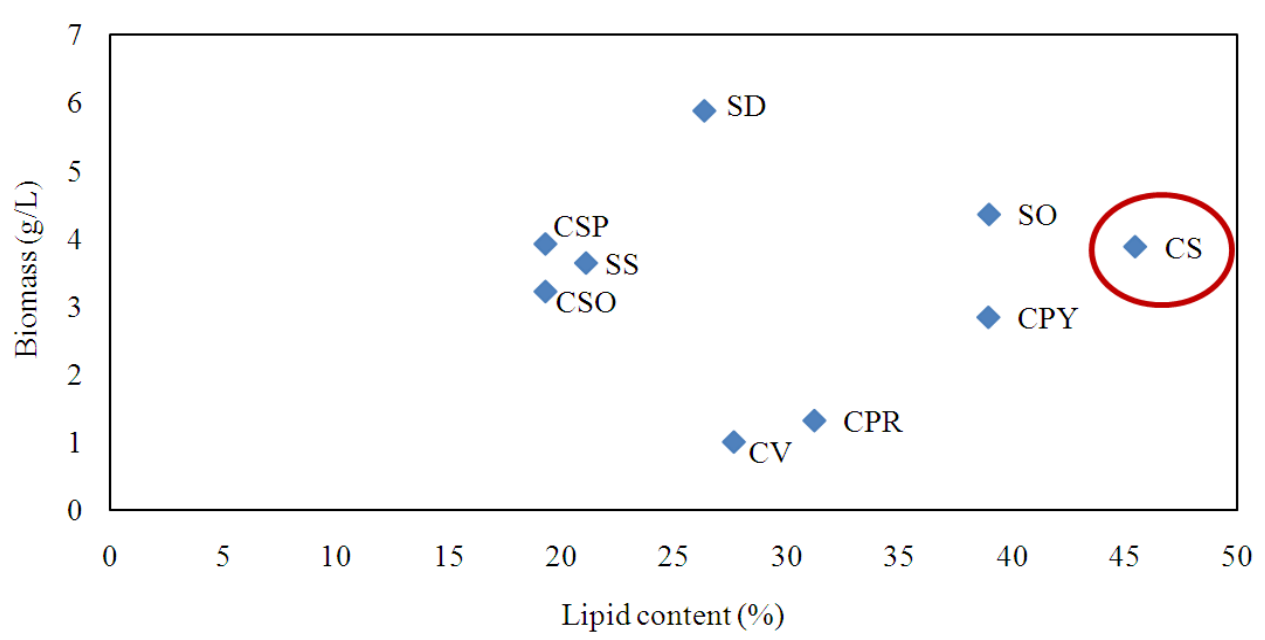

Fig. 2. Biomass Vs. lipid content of freshwater microalgae species (BB: Botryococcus brauni, CPR: Chlorella protothecides, CS: Chlorella saccharophila, CSO: Chlorella sorokiniana, CV: Chlorella vulgaris, CSP: Chlorococcum sp., SD: Scenedesmus dimorphus, SO: Scenedesmus obliqus, SS: Scenedesmus sp)

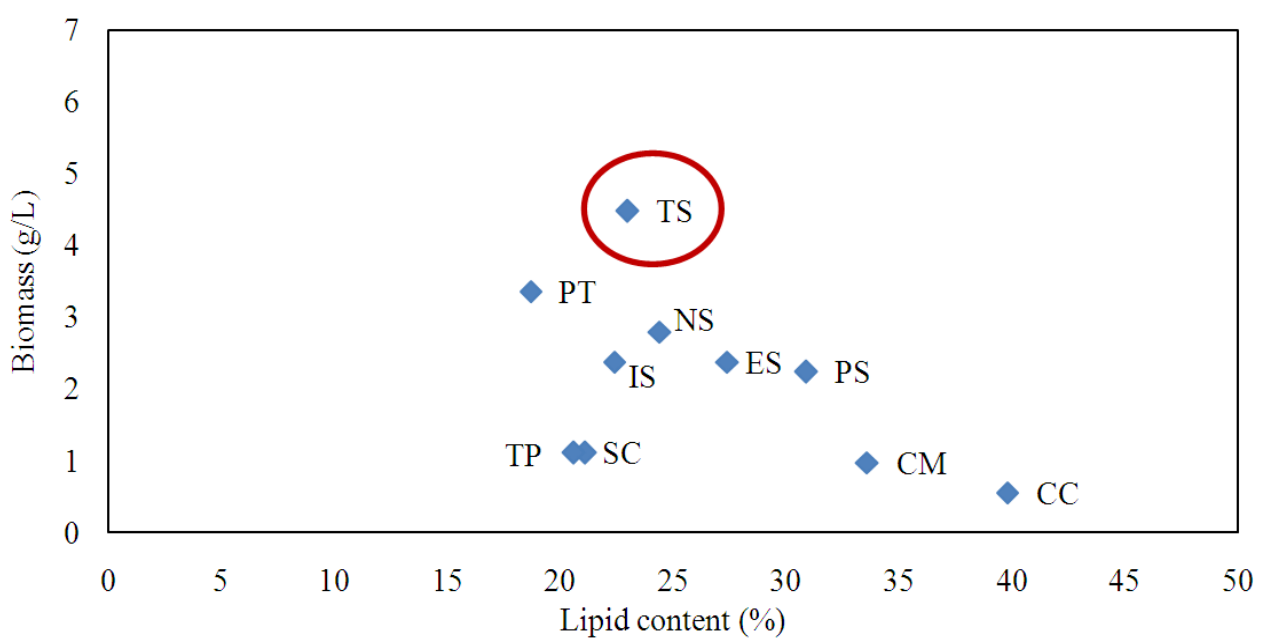

Fig. 3. Biomass Vs. lipid content of marine microalgae species (CC: Chaetoceros calcitrans, CM: Chaetoceros muelleri, SC: Skeletonema costatum, TP: Thalassiosira pseudonana, PS: Pavlova salina, ES: Ellipsoidion sp., IS: Isochrysis sp., NS: Nannochloropsis sp., PT: Phaeodactylum tricornutum, TS: Tetraselmis suecica, TP: Thalassiosira pseudonana)

\section{Experimental Design}

The selected freshwater (Chlorella saccharophila) and marine (Tetraselmis suecica) microalgae species were grown under various environmental conditions in the open pond system. The effects of light duration and nutrient on the algae biomass and oil content were evaluated using $\mathrm{NaHCO}_{3}$ as a carbon source while maintaining the nitrogen content, $\mathrm{pH}$ and temperature constant at $70 \mathrm{mg} / \mathrm{L}$, 8.3-8.9 and $22^{\circ} \mathrm{C}$, respectively. Sodium bicarbonate $\left(\mathrm{NaHCO}_{3}\right)$ was administered at a concentration of 1300 $\mathrm{mg} / \mathrm{L}$. The light intensity was kept at $480 \mu \mathrm{mol} \mathrm{m}^{-2} \mathrm{~s}^{-1}$ and the algae was exposed to three light periods throughout the cultivation process: (a) the shortest day light in the winter of $\sim 9 \mathrm{~h}$, (b) the longest day light in the summer of $\sim 16 \mathrm{~h}$ and (c) full light exposure $(24 \mathrm{~h})$ using the automated lighting and control units in the open pond system. Ammonium nitrate, ammonium phosphate, ammonium sulfate and a mix of all three were evaluated as sources of nitrogen (Table 2). Each experiment was carried out for 10 days with three replicates, giving a grand total of 72 runs for both species.

\section{Preparation of Liquid Medium for Inoculum Growth}

The freshwater microalgae medium was prepared on algal proteose medium (ATCC Catalog Medium No. 847, American Type Culture Collection, Manassas, VA, USA) and was made up by adding $1 \mathrm{~g}$ of proteose Peptone (Difco 0120) to $1 \mathrm{~L}$ of Bristols solution (Table 3). Bristols solution was prepared by adding the 


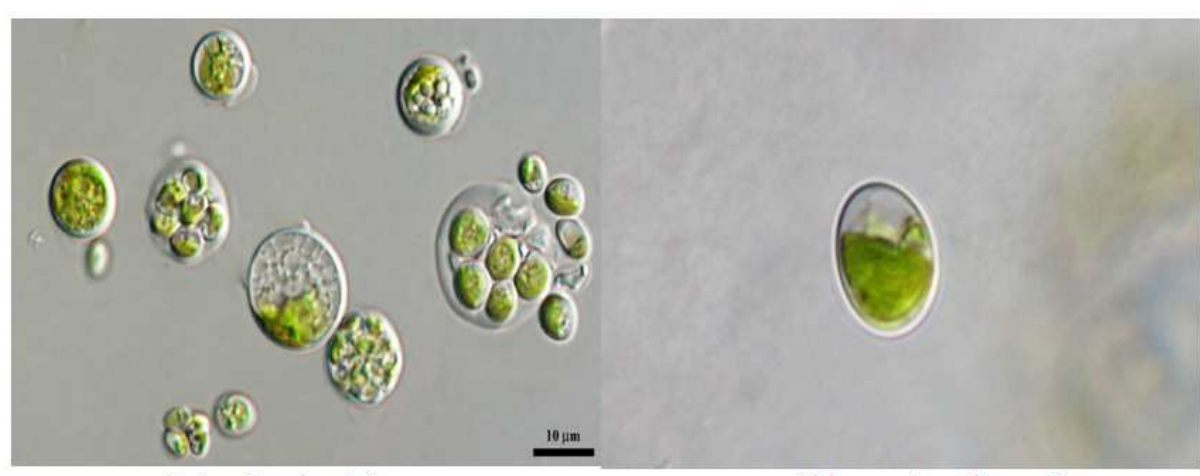

Subspherical form Chloroplast in cell

(a) Chlorella saccharophila (Skaloud, 2007)

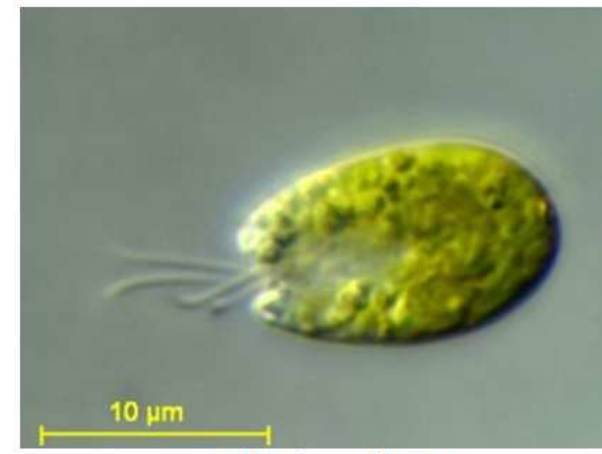

Elliptic cell type

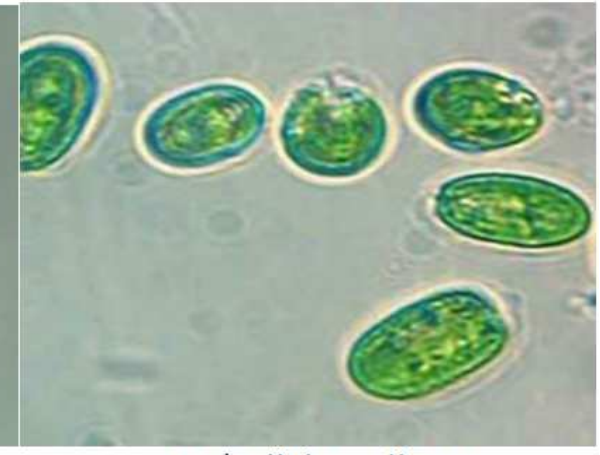

Unicellular cell type

(b) Tetraselmis suecica (Reefsnow, 2012)

Fig. 4. Microscopic illustrations of Chlorella saccharophila and Tetraselmis suecica

Table 2. Concentration of micronutrient components

\begin{tabular}{|c|c|c|c|c|c|}
\hline \multirow[b]{2}{*}{ Compound } & \multirow[b]{2}{*}{$\begin{array}{l}\text { Molecular } \\
\text { Weight }(\mathrm{g} / \mathrm{mol})\end{array}$} & \multirow[b]{2}{*}{$\begin{array}{l}\text { Amount } \\
(\mathrm{mg} / \mathrm{L})\end{array}$} & \multicolumn{3}{|c|}{ Concentration (mg/L) } \\
\hline & & & Nitrogen & Phosphorus & Sulfur \\
\hline Ammonium nitrate $\left(\mathrm{NH}_{4} \mathrm{NO}_{3}\right)$ & 80 & 200.0 & 70 & \multirow{3}{*}{78} & \multirow{6}{*}{80} \\
\hline Diammonium phosphate $\left(\mathrm{NH}_{4}\right)_{2} \mathrm{HPO}_{4}$ & 132 & 330.0 & 70 & & \\
\hline Ammonium sulfate $\left(\mathrm{NH}_{4} \mathrm{SO}_{4}\right)$ & 132 & 330.0 & 70 & & \\
\hline Combination & & & & & \\
\hline Ammonium nitrate $\left(\mathrm{NH}_{4} \mathrm{NO}_{3}\right)$ & 80 & 85.7 & 30 & \multirow{3}{*}{22} & \\
\hline Diammonium phosphate $\left(\mathrm{NH}_{4}\right)_{2} \mathrm{HPO}_{4}$ & 132 & 194.3 & 20 & & \\
\hline Ammonium sulfate $\left(\mathrm{NH}_{4} \mathrm{SO}_{4}\right)$ & 132 & 94.3 & 20 & & 23 \\
\hline
\end{tabular}

following amounts from the prepared stock solutions: 10 $\mathrm{mL} \mathrm{NaNO}_{3}, 10 \mathrm{~mL} \mathrm{CaCl}_{2}, 10 \mathrm{~mL} \mathrm{MgSO}_{4} 7 \mathrm{H}_{2} \mathrm{O}, 10 \mathrm{~mL}$ $\mathrm{K}_{2} \mathrm{HPO}_{4}, 10 \mathrm{~mL} \mathrm{KH} \mathrm{PO}_{4}, 10 \mathrm{~mL} \mathrm{NaCl}, 0.05 \mathrm{~mL} \mathrm{FeCl}_{3}$ and $940 \mathrm{~mL}$ distilled water. The stock solutions were prepared as follows: $10 \mathrm{~g} \mathrm{NaNO}_{3}$ in $400 \mathrm{~mL}$ distilled water, $1 \mathrm{~g} \mathrm{CaCl}_{2}$ in $400 \mathrm{~mL}$ distilled water, $3 \mathrm{~g} \mathrm{MgSO}_{4}$ $7 \mathrm{H}_{2} \mathrm{O}$ in $400 \mathrm{~mL}$ distilled water, $3 \mathrm{~g} \mathrm{~K}_{2} \mathrm{HPO}_{4}$ in $400 \mathrm{~mL}$ of distilled water, $7 \mathrm{~g} \mathrm{KH}_{2} \mathrm{PO}_{4}$ in $400 \mathrm{~mL}$ of distilled water and $1 \mathrm{~g} \mathrm{NaCl}$ in $400 \mathrm{~mL}$ distilled water.

The marine microalgae medium was prepared in $F / 2$ medium (Guillard and Ryther, 1962). The trace element liquid medium stock solution (Table 4) was prepared by the addition of $4.16 \mathrm{~g} \mathrm{Na}_{2}$ EDTA, $3.15 \mathrm{~g} \mathrm{FeCl}_{3} \cdot 6 \mathrm{H}_{2} \mathrm{O}$, $0.01 \mathrm{~g} \mathrm{CuSO}_{4} \cdot 5 \mathrm{H}_{2} \mathrm{O}, 0.022 \mathrm{~g} \mathrm{ZnSO}_{4} \cdot 7 \mathrm{H}_{2} \mathrm{O}, 0.01 \mathrm{~g}$
$\mathrm{CoCl}_{2} \cdot 6 \mathrm{H}_{2} \mathrm{O}, \quad 0.18 \mathrm{~g} \quad \mathrm{MnCl}_{2} \bullet 4 \mathrm{H}_{2} \mathrm{O}$ and $0.006 \mathrm{~g}$ $\mathrm{Na}_{2} \mathrm{MoO}_{4} \cdot 2 \mathrm{H}_{2} \mathrm{O}$ into $1 \mathrm{~L}$ autoclaved seawater (Halifax Waterfront, Halifax, Nova Scotia). The vitamin mix stock solution was prepared by the addition of $0.1 \mathrm{~g}$ Thiamine $\mathrm{HCl}$ and $0.0005 \mathrm{~g}$ biotin into $1 \mathrm{~L}$ autoclaved seawater. The liquid medium was prepared by the addition of $0.075 \mathrm{~g}$ $\mathrm{NaNO}_{3}, 0.00565 \mathrm{~g} \mathrm{NaH}_{2} \mathrm{PO}_{4} \cdot 2 \mathrm{H}_{2} \mathrm{O}, 1.0 \mathrm{~mL}$ trace element stock solution and $1 \mathrm{ml}$ of vitamin mix stock solution.

\section{Preparation of Solid Medium for Inoculum Growth}

The marine microalgae grow only on a marine liquid medium. The freshwater microalgae solid medium was prepared on algal proteose agar medium (ATCC Catalog Medium No. 847). The solid medium (Table 3) was 


\begin{tabular}{|c|c|c|}
\hline \multirow[b]{2}{*}{ Component } & \multicolumn{2}{|l|}{ Quantity } \\
\hline & $\begin{array}{l}\text { Proteose agar } \\
\text { medium }\end{array}$ & $\begin{array}{l}\text { Proteose } \\
\text { broth medium }\end{array}$ \\
\hline Agar $(g)$ & 15.00 & \\
\hline Proteose peptone $(\mathrm{g})$ & 1.00 & 1.00 \\
\hline Bristols solution (L) & 1.00 & 1.00 \\
\hline $\mathrm{NaNO}_{3}$ Solution $(\mathrm{mL})$ & 10.00 & 10.00 \\
\hline $\mathrm{CaCl}_{2}$ Solution $(\mathrm{mL})$ & 10.00 & 10.00 \\
\hline $\mathrm{MgSO}_{4} \cdot 7 \mathrm{H}_{2} \mathrm{O}$ Solution $(\mathrm{mL})$ & 10.00 & 10.00 \\
\hline $\mathrm{K}_{2} \mathrm{HPO}_{4}$ Solution $(\mathrm{mL})$ & 10.00 & 10.00 \\
\hline $\mathrm{KH}_{2} \mathrm{PO}_{4}$ Solution $(\mathrm{mL})$ & 10.00 & 10.00 \\
\hline $\mathrm{NaCl}$ Solution $(\mathrm{mL})$ & 10.00 & 10.00 \\
\hline $\mathrm{FeCl}_{3}$ Solution $(\mathrm{mL})$ & 0.05 & 0.05 \\
\hline Distilled Water (mL) & 940.00 & 940.00 \\
\hline
\end{tabular}

Table 4. Components of the $\mathrm{F} / 2$ marine liquid media (Guillard and Ryther, 1962)

\begin{tabular}{ll}
\hline Component & Quantity $\left(\mathrm{g} / \mathrm{L}^{*}\right)$ \\
\hline Trace element stock solution & \\
$\mathrm{Na}_{2} \mathrm{EDTA}$ & 4.1600 \\
$\mathrm{FeCl}_{3} \cdot 6 \mathrm{H}_{2} \mathrm{O}$ & 3.1500 \\
$\mathrm{CuSO}_{4} \cdot 5 \mathrm{H}_{2} \mathrm{O}$ & 0.0100 \\
$\mathrm{ZnSO}_{4} \cdot 7 \mathrm{H}_{2} \mathrm{O}$ & 0.0220 \\
$\mathrm{CoCl}_{2} \cdot 6 \mathrm{H}_{2} \mathrm{O}$ & 0.0100 \\
$\mathrm{MnCl}_{2} \cdot 4 \mathrm{H}_{2} \mathrm{O}$ & 0.1800 \\
$\mathrm{Na}_{2} \mathrm{MoO}_{4} \cdot 2 \mathrm{H}_{2} \mathrm{O}$ & 0.0060 \\
Vitamin mix stock solution & \\
Thiamine $\mathrm{HCl}$ & 0.1000 \\
Biotin & 0.0005 \\
\hline
\end{tabular}

*per liter of autoclaved seawater

made up by the addition of $1 \mathrm{~g}$ proteose peptone (Difco 0120 ) and $15 \mathrm{~g}$ agar to $1 \mathrm{~L}$ Bristols solution.

\section{Preparation of Inoculum}

Sufficient amounts of inoculum were prepared for all the experimental runs for both freshwater and marine microalgae in order to maintain consistency. The procedures for preparing the inocula are depicted in Fig. 5.

The freeze dried Chlorella saccharophila sample (ATCC $\AA 30408^{\mathrm{TM}}$, Catalog Medium No. 847, American Type Culture Collection, Manassas, VA, USA) was revived in $5 \mathrm{~mL}$ of Bristols liquid media. Using an inoculating loop, cells were transferred from the liquid media onto 3 petri dishes containing proteose agar media. The plates were incubated for 3 days at room temperature and a photocycle of $14 \mathrm{~h}$ light and $10 \mathrm{~h}$ dark. The cells were then scraped off the solid media using an inoculating loop and submerged them into a $125 \mathrm{~mL}$ Erlenmeyer flask containing $25 \mathrm{~mL}$ of Bristols liquid medium. These cells were then left to grow for 2 weeks at a photocycle of $14 \mathrm{~h}$ light and 10 $\mathrm{h}$ dark. The mixture was then transferred to a $500 \mathrm{~mL}$ Erlenmeyer flask containing $250 \mathrm{~mL}$ of Bristols liquid media which was left to grow for 2 weeks at a photocycle of $14 \mathrm{~h}$ light and $10 \mathrm{~h}$ dark. Finally, the medium was transferred from the $500 \mathrm{~mL}$ flask into a $30 \mathrm{~L}$ bioreactor containing $25 \mathrm{~L}$ of Bristols liquid media and left to grow for 2 more weeks at a photocycle of $14 \mathrm{~h}$ light and $10 \mathrm{~h}$ dark.

The inoculum for Tetraselmis suecica microalga was prepared by taking $5 \mathrm{~mL}$ of the liquid sample (UTEX LB 2286, Cedarlane, Burlington, Ontario)and adding it to $125 \mathrm{~mL}$ Erlenmeyer flask containing 25 $\mathrm{mL}$ of $\mathrm{F} / 2$ liquid medium and then left to grow at room temperature for 2 weeks at a photocycle of $14 \mathrm{~h}$ light and $10 \mathrm{~h}$ dark. The mixture was then transferred to a $500 \mathrm{~mL}$ Erlenmeyer flask containing $250 \mathrm{~mL}$ of $\mathrm{F} / 2$ liquid media and was left to grow for 2 weeks at a photocycle of $14 \mathrm{~h}$ light and $10 \mathrm{~h}$ dark. Finally, the medium was transferred from the $500 \mathrm{~mL}$ flask into a $30 \mathrm{~L}$ bioreactor containing $25 \mathrm{~L}$ of $\mathrm{F} / 2$ liquid media and left to grow for 2 additional weeks at a cycle of $14 \mathrm{~h}$ light and $10 \mathrm{~h}$ dark.

\section{Preparation of Algae Production Media}

The freshwater production medium is a modification of the Fitzgerlad medium (Hughes et al., 1959). The preparation of the stock solutions for this media is shown in Table 5. The medium was made up by the addition of $1 \mathrm{~mL}$ of each of the stock solutions $\mathrm{A}, \mathrm{B}, \mathrm{C}$ and $\mathrm{D}$ into $1 \mathrm{~L}$ distilled water (Table 6).

A modified F/2 medium (Guillard and Ryther, 1962) was used as the production medium for the marine microalga. The medium was modified by eliminating the addition of sodium nitrate. The medium consists primarily of autoclaved ocean water (Halifax Waterfront, Halifax, NS, Canada). Table 7 shows the elemental analysis of the components present in the marine water which was performed at the Mineral Engineering Center of Dalhousie University.

\section{Experimental Protocol}

To each open pond a total of $4.75 \mathrm{~L}$ of freshwater production medium were added. The desired nutrient (ammonium nitrate, ammonium phosphate, ammonium sulfate or combination of all three) was added to the production medium. This solution was enriched with 1.3 $\mathrm{g} / \mathrm{L}$ of sodium bicarbonate (total of $6.5 \mathrm{~g}$ ) and $250 \mathrm{~mL}$ of Chlorella saccharophila inoculum was added to each pond. The cells were exposed to either 9,16 and $24 \mathrm{~h}$ or light and left to grow for 10 days. Every other day, 100 $\mathrm{mL}$ sample was taken for analyses. The biomass was harvested from the liquid media using a Sorvall T1 Centrifuge (Thermo Scientific, Ohio, USA). The supernatant from the centrifuge tubes was decanted and the cells were collected for biomass yield and oil content analyses. The marine medium was used with marine algae and the same procedure was followed. 


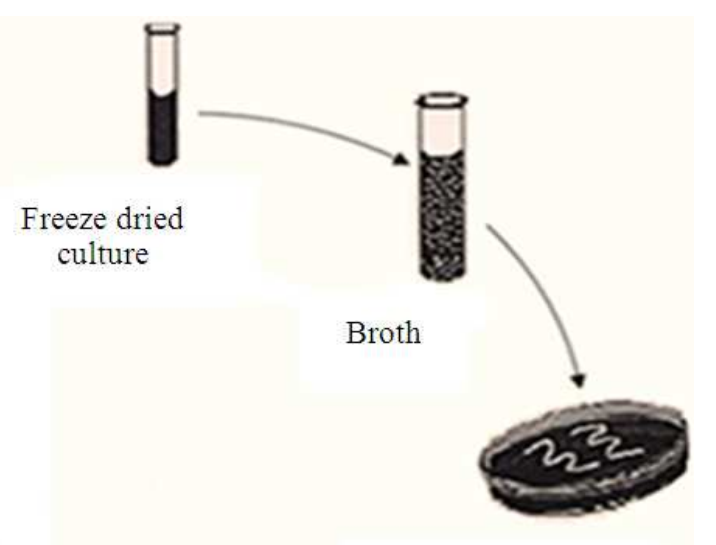

25 L Liquid broth bioreactor
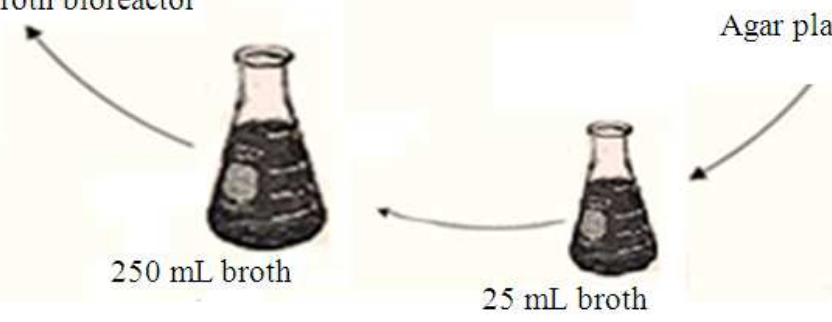

(a) Freshwater microalgae

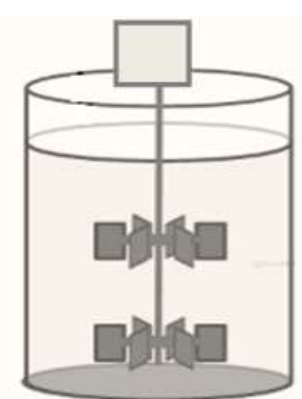

25 L Liquid broth bioreactor

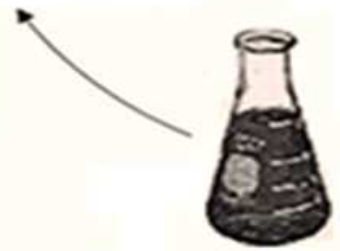

$250 \mathrm{~mL}$ broth

(b) Marine microalgae

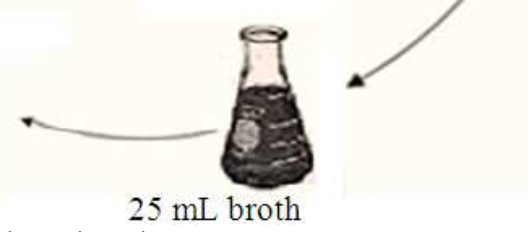

Liquid Sample

Fig. 5. Preparation of inocula

\section{Microalgae Biomass Determination}

The freshwater mciroagla biomass yield was determined by measuring the optical density at $484 \mathrm{~nm}$ from a standard curve between the cell count and optical density. The number of Colony Forming Units (CFU) for Chlorella saccharophila was determined using a series of dilutions. A $1 \mathrm{~mL}$ aliquot sample was added to a test tube containing $9 \mathrm{~mL}$ autoclaved distilled water. The contents of the tube were vortexed (Thermolyne Maxi
Mix, Thermolyne Corporation, Hampton, New Hampshire, USA) to distribute the cells. A $1 \mathrm{~mL}$ aliquot of this solution was added to another test tube containing $9 \mathrm{~mL}$ autoclaved distilled water. This tube was again vortexed to distribute the cells. This was repeated 7 times to obtain dilutions of 1:1, 1:10, 1:100, 1:1000, 1:10 000, 1:100 000, 1: 1000000 . For each of the dilutions made, $0.1 \mathrm{~mL}$ of the solution was added to a petri dish containing solid freshwater or marine water medium. The plates were sealed with parafilm, inverted and 


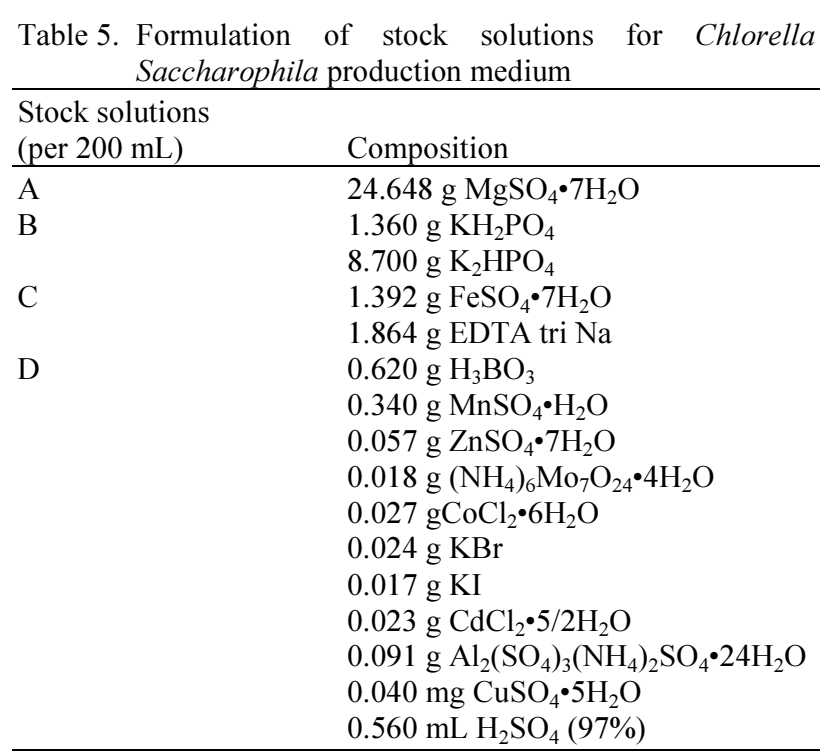

Table 6. Components of freshwater production medium

\begin{tabular}{lc}
\hline Component & Amount $(\mathrm{mL})$ \\
\hline A & 1 \\
B & 1 \\
C & 1 \\
D & 1 \\
Distilled water & 996
\end{tabular}

Table 7. Elemental analysis of autoclaved ocean water used as a marine production medium

\begin{tabular}{lr}
\hline Element & Amount $(\mathrm{mg} / \mathrm{L})$ \\
\hline $\mathrm{Na}$ & 10254.00 \\
$\mathrm{Mg}$ & 1078.00 \\
$\mathrm{~S}$ & 1010.00 \\
$\mathrm{~K}$ & 395.00 \\
$\mathrm{Ca}$ & 386.00 \\
$\mathrm{Sr}$ & 6.79 \\
$\mathrm{Si}$ & 2.80 \\
$\mathrm{P}$ & 0.10 \\
$\mathrm{Ba}$ & 0.05 \\
$\mathrm{Al}$ & 0.05 \\
$\mathrm{Ni}$ & 0.04 \\
$\mathrm{Zn}$ & 0.02 \\
$\mathrm{Mo}$ & 0.01 \\
$\mathrm{Cd}$ & 0.01 \\
$\mathrm{Co}$ & 0.01 \\
$\mathrm{Cu}$ & 0.01 \\
\hline
\end{tabular}

incubated at room temperature $\left(\sim 24^{\circ} \mathrm{C}\right)$ at a photo cycle of $14 \mathrm{~h}$ light and $10 \mathrm{~h}$ dark for 3 days. The plates were then removed and the colonies were counted using a colony counter (Model No. 7-910, Fisher Scientific, Ottawa, Ontario). The plates consisting of 30-300 CFU were used for calculating the CFU of the sample and the standard curve was prepared by plotting the optical density against the CFU (Fig. 6a). The following equation was used to calculate Chlorella saccharophila cell yield:
Cell Yield $=\left(\frac{\text { Optical Density }}{5 \times 10^{-7}}\right) \times 10^{3}$

The marine microalgae yield was also determined by optical density measurements. A standard curve between the cell count and optical density (measured at $750 \mathrm{~nm}$ ) was developed (Fig. 6b) and the following equation was used to calculate Tetraselmis suecica cell yield:

Cell Yield $=\left(\frac{\text { Optical Density }}{23 \times 10^{-4}}\right) \times 10^{4}$

\section{Oil Content Determination}

The oil content in the algae was determined using ultrasound assisted solvent extraction according to Bligh and Dyer method described by Araujo et al. (2013). Firstly, the algae biomass was homogenized and mixed with $25 \mathrm{~mL}$ methanol, $12.5 \mathrm{~mL}$ chloroform and $5 \mathrm{~mL}$ distilled deionized water. This mixture was exposed to ultrasonic energy (Branson 2510R-DTH, Branson Ultrasonics Corporation, Danbury, USA) for $40 \mathrm{~min}$. Then, an additional $12.5 \mathrm{~mL}$ chloroform and $12.5 \mathrm{~mL}$ sodium sulfate solution $(1.5 \% \mathrm{w} / \mathrm{v})$ were added and sonicated for another $20 \mathrm{~min}$. The solid biomass particles were filtered out of the solution and the liquid fraction was transferred to a separatory funnel with the addition of $75 \mathrm{~mL} \mathrm{KCl}(0.88 \% \mathrm{w} / \mathrm{v})$. The mixture was vigorously shaken and left to separate for $24 \mathrm{~h}$. The solubility of oils in the chloroform solvent and the insolubility of solvents in water allowed for separation to occur into two phases (organic and aqueous). The oil containing phase (on the bottom) was drained out of the separatory funnel and collected into a pre-weighed distill flask. The flask was distilled using a rotary evaporator (HiTEC RE-51, Yamato Scientific America, California, USA) set at $45^{\circ} \mathrm{C}$. The oil left behind was weighed in the flask and the yield was determined as follows:

$$
\text { Oil Yield }(\%)=\frac{\text { weight of } \operatorname{Oil}(g)}{\text { weight of Algae Biomass }(g)} \times 100
$$

\section{Results and Discussion}

\section{Microalgae Biomass}

The cell number results are shown in Table 8 . Analysis of the Variance (ANOVA) was performed on the cell yield data as shown in Table 9 using Minitab statistics software (Minitab ${ }^{\circledR}$ 16.2.2., Minitab Inc., Canada). The effects of microalgae type, light duration and nitrogen source on the cell yield were significant at the 0.001 level. There were also significant interactions 


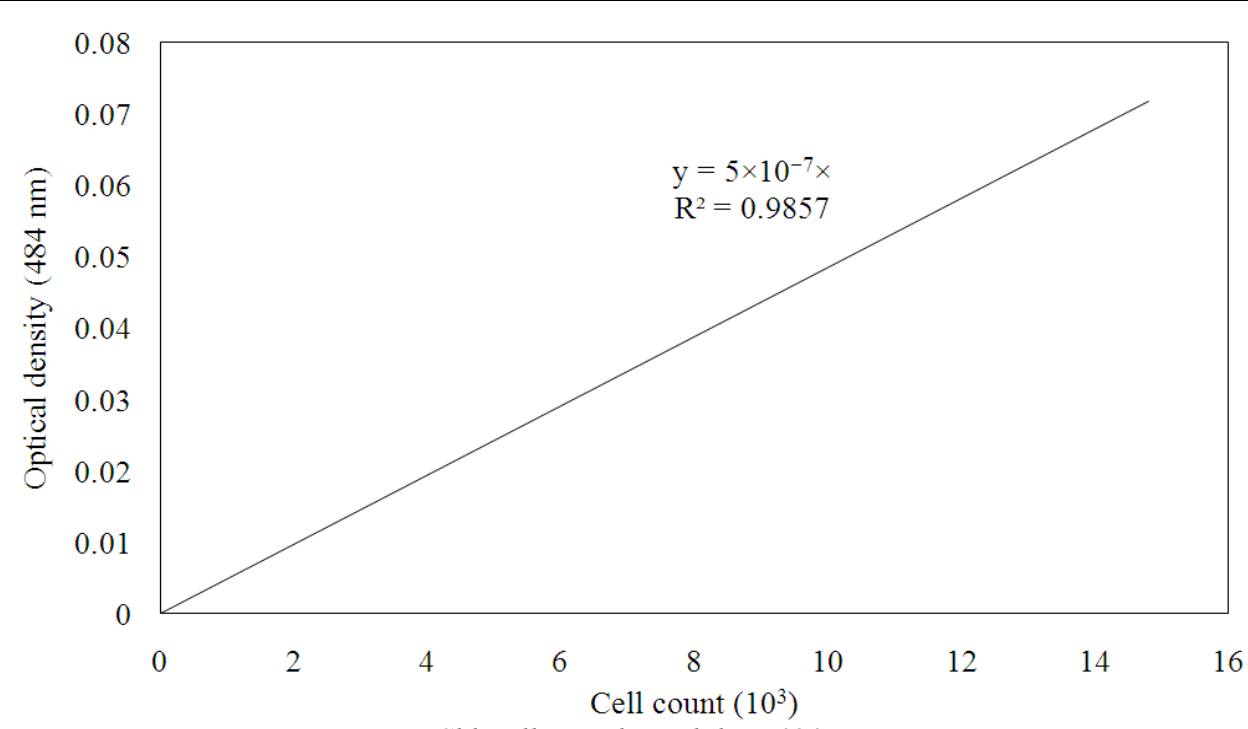

(a) Chlorella saccharophila at $484 \mathrm{~nm}$

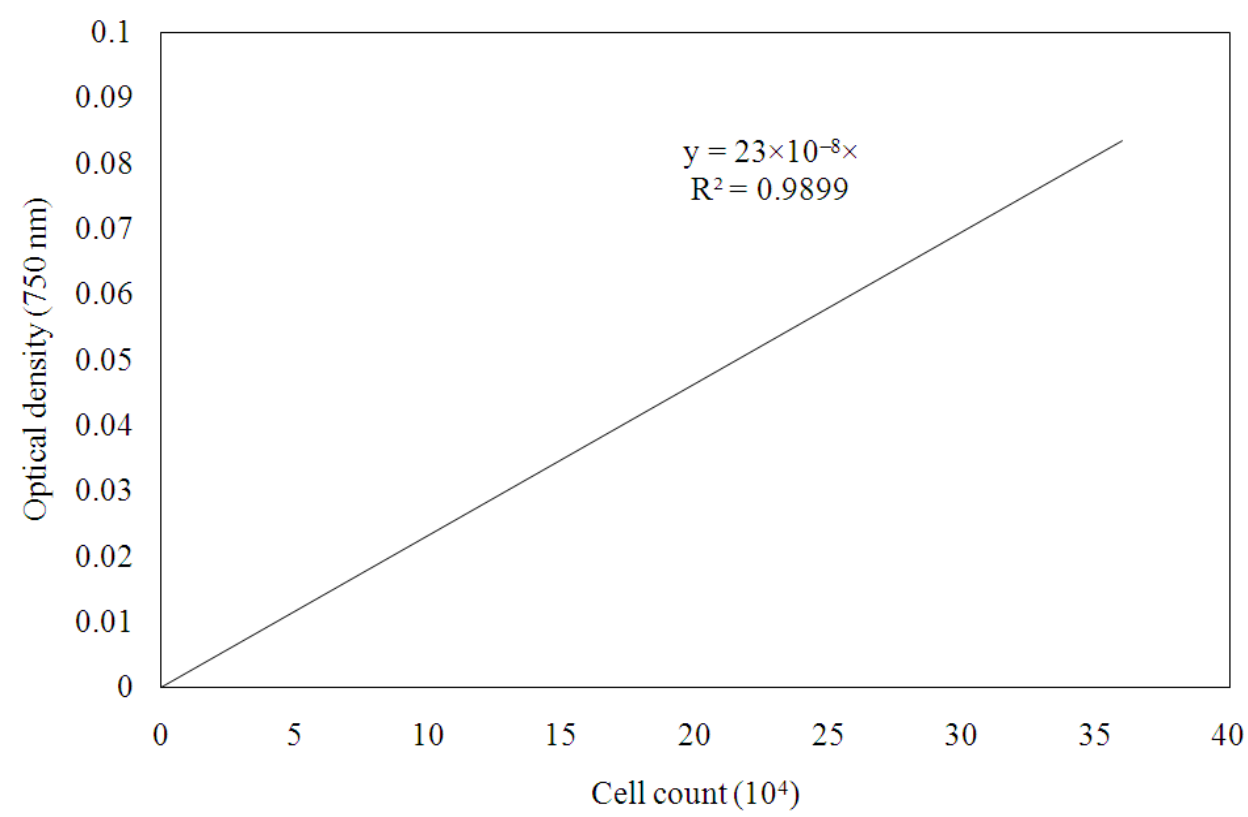

(b) Tetraselmis suecica at $750 \mathrm{~nm}$

Fig. 6. Standard curves

between these parameters. Tukey's grouping was used to test the differences among the levels of each parameter as shown in Table 10. The two algae were significantly different from one another at the 0.05 level. The marine microalgae Tetraselmis suecica had the highest mean cell yield $\left(2.89 \times 10^{6}\right.$ cells $\left./ \mathrm{mL}\right)$. The nutrients ammonium nitrate, ammonium phosphate and ammonium sulfate were not significantly different from one another, but were significantly different from the nutrient combination at the 0.05 level. The highest mean cell yield of $4.01 \times 10^{6}$ cells $/ \mathrm{mL}$ was achieved using the combination of nutrients. The light exposures
16 and $24 \mathrm{~h}$ were not significantly different from one another, but were significantly different from the $9 \mathrm{~h}$ light exposure at the 0.05 level. However, the highest mean cell yield of $2.28 \times 10^{6}$ cells $/ \mathrm{mL}$ was achieved at $24 \mathrm{~h}$ light exposure.

\section{Effect of Microalgae Type}

The effects of microalgae type on the cell yield are shown in Fig. 7. Tetraselmis suecica achieved higher cell yields than the Chlorella saccharophila at all nutrient types and light durations. Tetraselmis suecica achieved cell yields of $0.266 \times 10^{6}, 1.664 \times 10^{6}$, 
Table 8. Average cell number and oil content of Chlorella saccharophila (freshwater) and Tetraselmis suecica (marine) microalgae using various nitrogen sources at different light exposures

\begin{tabular}{|c|c|c|c|c|}
\hline Species & Nutrient type & Light (h) & Cell number (cells/mL) & Oil content $(\%)$ \\
\hline \multirow[t]{12}{*}{ Freshwater } & \multirow[t]{3}{*}{ Ammonium nitrate } & 9 & $0.279 \times 10^{6} \pm 0.07 \times 10^{6}$ & $14.162 \pm 4.85$ \\
\hline & & 16 & $0.336 \times 10^{6} \pm 0.05 \times 10^{6}$ & $13.176 \pm 2.58$ \\
\hline & & 24 & $0.460 \times 10^{6} \pm 0.04 \times 10^{6}$ & $7.714 \pm 3.44$ \\
\hline & \multirow[t]{3}{*}{ Ammonium phosphate } & 9 & $0.138 \times 10^{6} \pm 0.03 \times 10^{6}$ & $29.075 \pm 13.40$ \\
\hline & & 16 & $0.186 \times 10^{6} \pm 0.05 \times 10^{6}$ & $27.353 \pm 1.43$ \\
\hline & & 24 & $0.489 \times 10^{6} \pm 0.08 \times 10^{6}$ & $7.861 \pm 2.24$ \\
\hline & \multirow[t]{3}{*}{ Ammonium sulfate } & 9 & $0.139 \times 10^{6} \pm 0.02 \times 10^{6}$ & $13.247 \pm 0.58$ \\
\hline & & 16 & $0.157 \times 10^{6} \pm 0.03 \times 10^{6}$ & $7.168 \pm 1.00$ \\
\hline & & 24 & $0.507 \times 10^{6} \pm 0.09 \times 10^{6}$ & $3.782 \pm 3.56$ \\
\hline & \multirow[t]{3}{*}{ Combination } & 9 & $0.295 \times 10^{6} \pm 0.02 \times 10^{6}$ & $22.443 \pm 17.6$ \\
\hline & & 16 & $0.630 \times 10^{6} \pm 0.03 \times 10^{6}$ & $18.781 \pm 0.89$ \\
\hline & & 24 & $0.689 \times 10^{6} \pm 0.01 \times 10^{6}$ & $12.907 \pm 7.85$ \\
\hline \multirow[t]{12}{*}{ Marine } & \multirow[t]{3}{*}{ Ammonium nitrate } & 9 & $0.266 \times 10^{6} \pm 0.08 \times 10^{6}$ & $2.742 \pm 0.76$ \\
\hline & & 16 & $0.619 \times 10^{6} \pm 0.02 \times 10^{6}$ & $1.482 \pm 1.03$ \\
\hline & & 24 & $0.750 \times 10^{6} \pm 0.02 \times 10^{6}$ & $1.102 \pm 0.67$ \\
\hline & \multirow[t]{3}{*}{ Ammonium phosphate } & 9 & $1.664 \times 10^{6} \pm 0.05 \times 10^{6}$ & $1.876 \pm 0.78$ \\
\hline & & 16 & $2.122 \times 10^{6} \pm 0.58 \times 10^{6}$ & $1.213 \pm 1.38$ \\
\hline & & 24 & $2.354 \times 10^{6} \pm 0.10 \times 10^{6}$ & $0.640 \pm 0.55$ \\
\hline & \multirow[t]{3}{*}{ Ammonium sulfate } & 9 & $0.664 \times 10^{6} \pm 0.02 \times 10^{6}$ & $2.158 \pm 0.43$ \\
\hline & & 16 & $0.978 \times 10^{6} \pm 0.01 \times 10^{6}$ & $1.589 \pm 1.70$ \\
\hline & & 24 & $2.793 \times 10^{6} \pm 0.02 \times 10^{6}$ & $1.175 \pm 0.31$ \\
\hline & \multirow[t]{3}{*}{ Combination } & 9 & $2.689 \times 10^{6} \pm 0.02 \times 10^{6}$ & $0.450 \pm 0.21$ \\
\hline & & 16 & $9.415 \times 10^{6} \pm 0.06 \times 10^{6}$ & $0.435 \pm 0.16$ \\
\hline & & 24 & $10.342 \times 10^{6} \pm 0.13 \times 10^{6}$ & $0.270 \pm 0.06$ \\
\hline
\end{tabular}

Values are the average of three replicates

Table 9. Analysis of the variance for cell yield

\begin{tabular}{lcllrl}
\hline Source & DF & SS & MS & F & P \\
\hline Total & 71 & $5.854 \times 10^{14}$ & & \\
Model & & & & 60.29 & 0.001 \\
Species (S) & 1 & $1.152 \times 10^{14}$ & $4.151 \times 10^{14}$ & 24.65 & 0.001 \\
Nutrient (N) & 3 & $1.413 \times 10^{13}$ & $1.448 \times 10^{13}$ & 7.58 & 0.001 \\
Light (L) & 2 & $2.896 \times 10^{13}$ & $4.092 \times 10^{13}$ & 21.42 & 0.001 \\
S*N & 3 & $1.228 \times 10^{14}$ & $9.469 \times 10^{12}$ & 4.96 & 0.010 \\
S*L & 2 & $1.894 \times 10^{13}$ & $5.909 \times 10^{12}$ & 3.09 & 0.010 \\
N*L & 6 & $3.546 \times 10^{13}$ & $5.193 \times 10^{12}$ & 2.72 & 0.020 \\
S*N*L & 6 & $3.116 \times 10^{13}$ & $1.910 \times 10^{12}$ & & \\
Error & 48 & $9.169 \times 10^{13}$ & &
\end{tabular}

DF: Degrees of Freedom; SS: Sum of Squares; MS: Mean Sum of Squares; F: F Distribution; P: Probability-Value; R ${ }^{2}=84.34 \%$; CV $=17.69 \%$

Table 10. Tukey's grouping for cell yield

\begin{tabular}{|c|c|c|c|c|}
\hline Factors & Level & $\mathrm{N}$ & Mean yield & Tukey's grouping \\
\hline \multirow[t]{2}{*}{ Species } & Freshwater & 36 & 358921 & $\mathrm{~B}$ \\
\hline & Marine water & 36 & 2888406 & A \\
\hline \multirow[t]{4}{*}{ Nutrient } & Ammonium nitrate & 18 & 451837 & A \\
\hline & Ammonium sulfate & 18 & 873226 & A \\
\hline & Ammonium phosphate & 18 & 1159062 & A \\
\hline & Combination & 18 & 4010527 & $\mathrm{~B}$ \\
\hline \multirow[t]{3}{*}{ Light (h) } & 9 & 24 & 766963 & A \\
\hline & 16 & 24 & 1821984 & B \\
\hline & 24 & 24 & 2282043 & $\mathrm{~B}$ \\
\hline
\end{tabular}

Groups with the same letter are not significantly different from each other at the 0.05 level 


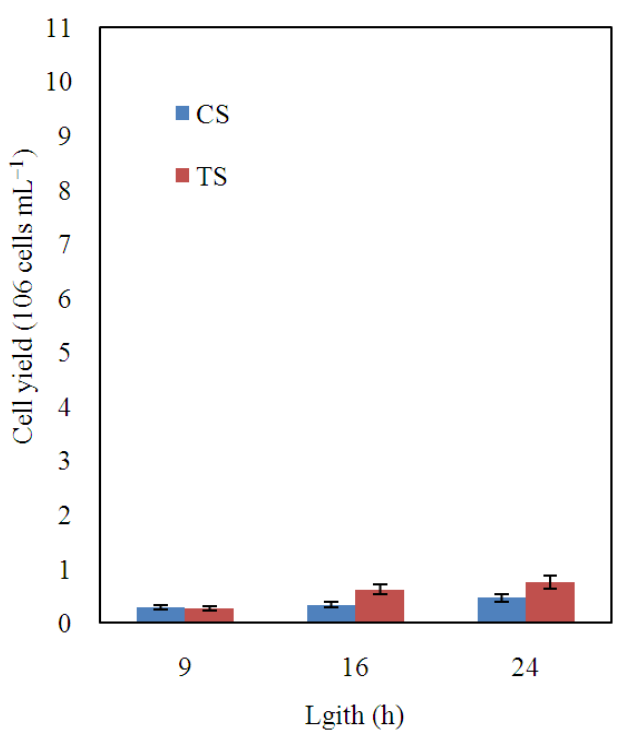

(a) Ammonium nitrate

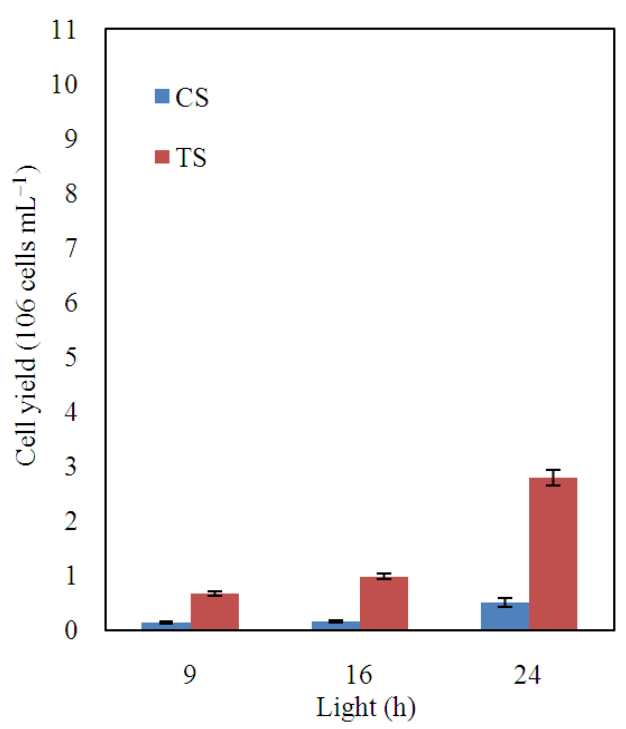

(c) Ammonium sulfate

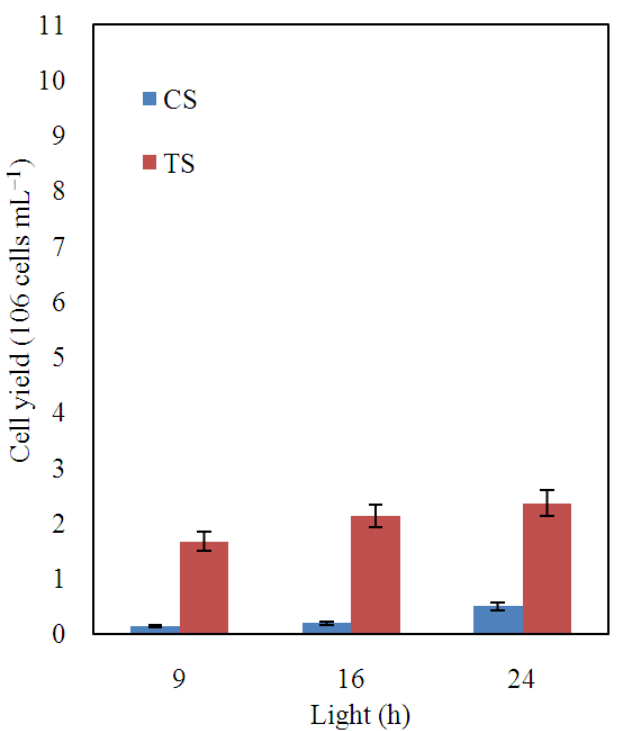

(b) Ammonium phosphate

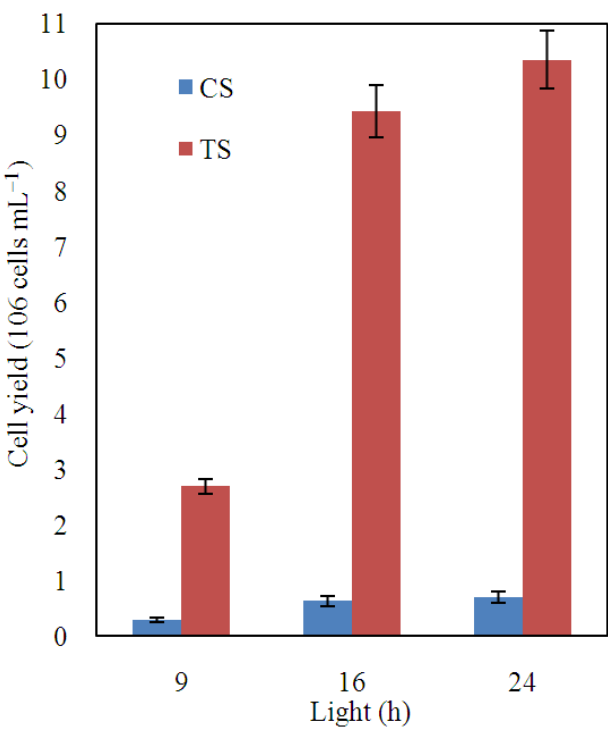

(d) Combination of nutrients

Fig. 7. Effect of microalgae type on the cell yield (cells $/ \mathrm{mL}$ ) at different nutrients light exposures (CS: Chlorella saccharophila, TS: Tetraselmis suecica)

$0.664 \times 10^{6}$ and $2.689 \times 10^{6}$ cells $/ \mathrm{mL}$ while Chlorella saccharophila achieved cell yields of $0.28 \times 10^{6}$, $0.14 \times 10^{6}, 0.14 \times 10^{6}$ and $0.30 \times 10^{6}$ cells $/ \mathrm{mL}$ at $9 \mathrm{~h}$ light exposure using ammonium nitrate, ammonium phosphate, ammonium sulfate and combination of nutrients, respectively. Similar trends were observed with other light exposures (16 and $24 \mathrm{~h}$ ).

Singh et al. (2013) reported a dry cell yield of 378 $\mathrm{mg} / \mathrm{L}$ for Chlorella saccharophila. Isleten-Hosoglu et al. (2012) reported a dry cell weight yield of $138 \mathrm{mg} / \mathrm{L}$ for Chlorella saccharophila. Herrera-Valencia et al. (2011) reported a biomass productivity of $154.3 \mathrm{mg} / \mathrm{L} / \mathrm{d}$ for Chlorella saccharophila. Chinnasamy et al. (2010) reported a biomass productivity of $23 \mathrm{mg} / \mathrm{L} / \mathrm{d}$ for Chlorella saccharophila. Danquah et al. (2010) reported a biomass yield $1.29 \mathrm{~g} / \mathrm{L}$ for the Tetraselmis suecica. Michels et al. (2013) achieved a biomass productivity of $350 \mathrm{mg} / \mathrm{L} / \mathrm{d}$ for Tetraselmis suecica. Thomas et al. (1984) reported a biomass productivity of $192 \mathrm{mg} / \mathrm{L} / \mathrm{d}$ for Tetraselmis suecica. Moheimani (2013) achieved a biomass productivity of $320 \mathrm{mg} / \mathrm{L} / \mathrm{d}$ for Tetraselmis suecica. Bondioli et al. (2012) noted a biomass productivity of $237 \mathrm{mg} / \mathrm{L} / \mathrm{d}$ for Tetraselmis suecica. These reports clearly indicate that both the cell yield and productivity were much higher for the marine microalga Tetraselmis suecica (1290-2480 mg/L) 
compared to the freshwater microalga Chlorella saccharophila (138-378 mg/L).

In this study the highest cell yield obtained for Chlorella saccharophila was $175 \mathrm{mg} / \mathrm{L}$ with a biomass productivity of $17.5 \mathrm{mg} / \mathrm{L} / \mathrm{d}$ while the highest cell yield obtained for Tetraselmis suecica was $2.48 \mathrm{~g} / \mathrm{L}$ with a biomass productivity of $247 \mathrm{mg} / \mathrm{L} / \mathrm{d}$. These results are within the range reported in the literature. The differences in the results can be attributed to the different growth conditions used and the varying harvesting techniques.

\section{Effect of Light}

The effect of light duration on the cell yield of
Chlorella saccharophila and Tetraselmis suecica is shown in Fig. 8. The results indicate a slight increase in cell yields as the light duration was increased for both microalgae species. For the ammonium sulfate nutrient, an increase in light duration from 9 to $24 \mathrm{~h}$, increased the cell yields from $0.138 \times 10^{6}$ cells $/ \mathrm{mL}$ to $0.368 \times 10^{6}$ cells $/ \mathrm{mL}$ and from $0.664 \times 10^{6}$ cells $/ \mathrm{mL}$ to $2.79 \times 10^{6}$ cells $/ \mathrm{mL}$ for the Chlorella Saccharophila and Tetraselmis suecica, respectively. Similar trends were observed with the other nutrients.

Al-Qasmi et al. (2012) stated that the biomass yield is directly linked to light duration. Larsdotter (2006) noted large fluctuations in algal biomass and removal of nutrients efficiencies due to seasonal variations in light and temperature. Khoeyi et al.

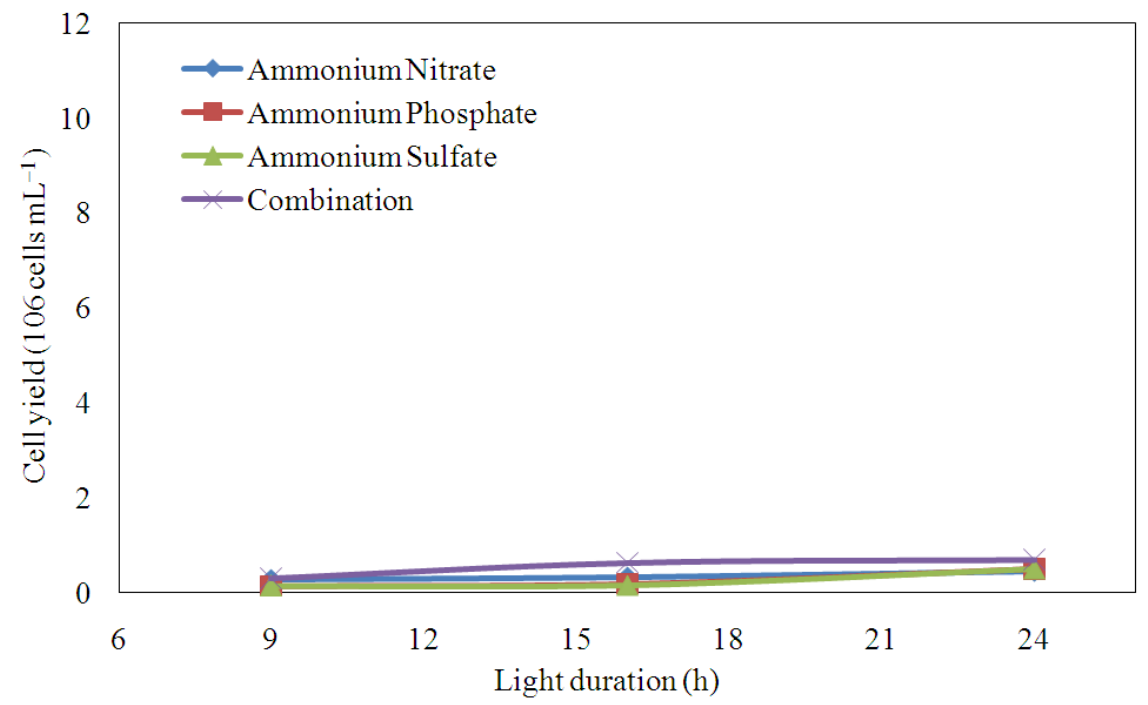

(a) Chlorella saccharophila

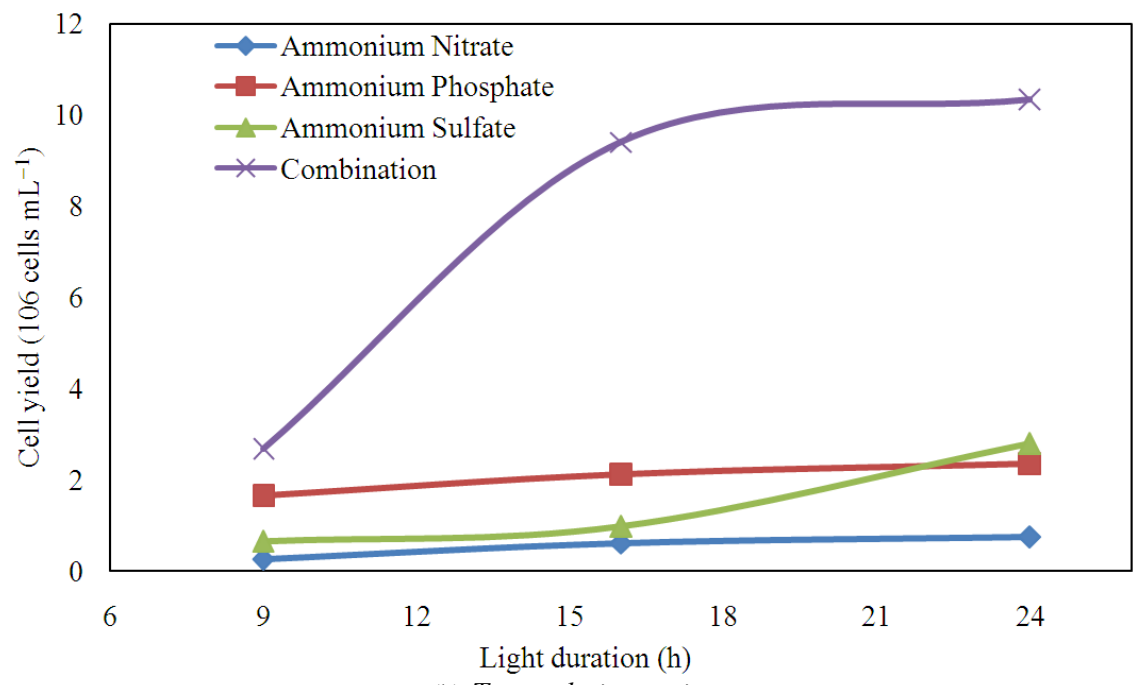

(b) Tetraselmis suecica

Fig. 8. Effect of light duration on the cell yield (cells $/ \mathrm{mL})$ of freshwater (Chlorella saccharophila) and marine (Tetraselmis suecica) microalgae using different nutrients 
(2012) reported Chlorella vulgaris cell numbers of $39 \times 10^{6}$ cells $/ \mathrm{mL}, \quad 60 \times 10^{6}$ cells $/ \mathrm{mL}$ and $75 \times 10^{6}$ cells $/ \mathrm{mL}$ at the light exposures of 8,12 and $16 \mathrm{~h}$, respectively. Wahidin et al. (2013) noted that Nannochlorpsissp. achieved an increase in cell concentration from $1.3 \times 10^{7}$ cells $/ \mathrm{mL}$ to $2.1 \times 10^{7}$ cells/mL as the light duration was increased from 12 to $18 \mathrm{~h}$. Mata et al. (2012) reported cell yields for Scenedesmus obliquus of 0.30 and $0.45 \mathrm{~g} / \mathrm{L}$ at light exposures periods of 12 and $24 \mathrm{~h}$, respectively.

The highest duration had exceptionally higher effect on the cell yield when the combination of nutrient was used. Increasing the light duration from 9 $\mathrm{h}$ to $24 \mathrm{~h}$ for this treatment increased the cell yield from $0.295 \times 10^{6}$ to $0.689 \times 10^{6}$ cells $/ \mathrm{mL}$ and $2.689 \times 106$ to $10.342 \times 106$ cells $/ \mathrm{mL}$ for Chlorella Saccharophila and Tetraselmis suecica, respectively. Increasing the light duration resulted in higher biomass production as a result of increased photosynthetic activity. Kaplan et al. (1986), Martinez et al. (1999), Hessen et al. (2002) and Sato and Murata (1980) reported that longer light exposures results in higher phosphorous uptake by the cells. Larsdotter (2006) reported that additional illumination in the winter for algal culture increased the uptake of phosphorus and nitrate uptake.

\section{Effect of Nutrient Type}

The effect of nutrient type on the cell yields of Chlorella saccharophila and Tetraselmis suecica microalgae is shown in Fig. 9. The combination of nutrients achieved the highest cell concentration for the two microalgae. The highest cell concentration of $0.295 \times 10^{6}, \quad 0.630 \times 10^{6}$ and $0.689 \times 10^{6}$ cells $/ \mathrm{mL}$ for Chlorella Saccharophila and the highest cell concentrations of $2.689 \times 10^{6}, 9.41 \times 10^{6}$ and $10.34 \times 10^{6}$ cells $/ \mathrm{mL}$ for Tetraselmis suecica were achieved using the combination of nutrient system at 9, 16 and $24 \mathrm{~h}$, respectively. The ammonium nitrate, ammonium phosphate and ammonium sulfate nutrients had similar effect on the cell yield cut were significantly less compared to the combined nutrients.

Becker (1994) stated that ammonia assimilation in microalgae is easier due to the simplicity of the molecule and its presence in a solution inhibits the nitrogenase activity. Odum (1983) noted that microalgae are capable of using nitrate because of its presence in nature.

Makareviciene et al. (2011) achieved the best biomass productivity of Chlorella sp. using sodium nitrate. Li et al. (2008) showed that $N$. oleoabundans increased in cell yield from 1.2 to $2.4 \mathrm{~g} / \mathrm{L}$ in day 2 using nitrate. Costa et al. (2001) reported that Spirulina platensis cell yields of $1.559,0.993$ and $0.081 \mathrm{~g} / \mathrm{L}$ when using sodium nitrate, ammonium nitrate and ammonium sulfate, respectively.
Abe et al. (2002) noted that Trentepohlia aurea biomass was 1.5 times higher in culture grown with sufficient nitrogen and phosphorus. Fried et al. (2003) stated a significant positive effect on algae growth with both nitrogen and phosphorus as nutrient sources. Li et al. (2011) noted that the species Scenedesmus $s p$. produced a higher cell productivity of $2.21 \times 10^{6}$ cells $/ \mathrm{mL} / \mathrm{d}$ with nitrogen and phosphorous contents of 12.1 and $0.27 \mathrm{mg} / \mathrm{L}$, respectively. Totsche et al. (2006) noted that the growth of Chlamydomonas $s p$. and Ochromonas $s p$. was stimulated with the addition of phosphorus into the media.

In this study, the ammonium sulfate did not prove to be suitable for yielding high biomass. Guzman-Murillo et al. (2007) noted that using ammonium sulfate as a nitrogen source for Phaeodactylum tricornutum species resulted in lower cell yields than ammonium nitrate. Rocha et al. (2003) also showed that an increase in ammonium sulphate concentration from $5 \mathrm{mM}$ to 10 $\mathrm{mM}$ decreased the cell concentration from $4 \times 10^{7}$ to $2.9 \times 10^{7}$ cells $/ \mathrm{mL}$. Costa et al. (2001) reported that freshwater algae Spirulina platensis achieving biomass yields of 0.993 and $0.081 \mathrm{~g} / \mathrm{L}$ using ammonium nitrate and ammonium sulfate, respectively. All these reported indicate that sulfate is not effective nutrient for promoting microalgae cell growth.

Different nutrients are responsible for the operation of different cell parts and lack of one nutrient affects the overall efficiency of the cells (Juan, 2006; Chen et al., 2009; Ji et al., 2013). In this study, the combination of nutrients (ammonium nitrate, ammonium phosphate, ammonium sulfate) provided the algae with a full spectrum of nutrients (nitrate, phosphate and ammonium) as opposed to the individual nutrients containing only nitrogen with one other element.

\section{Microalgae Oil Content}

The oil yield results are shown in Table 8. Analysis of the Variance (ANOVA) was performed on the oil yield data as shown in Table 11. The effects of microalgae type and nitrogen source on oil yield were significant at the 0.001 and 0.003 levels, respectively. However, the light duration did not have any significant effect. The interaction between the algae and nitrogen source also has a significant effect. However, the interactions between light duration, algae type and nitrogen source were not significant. Tukey's grouping was used to test the differences among the levels of each parameter as shown in Table 12. The two microalgae Chlorella saccharophila and Tetraselmis suecica were significantly different from one another at the 0.05 level. The highest mean oil yield (15.9\%) was obtained from 


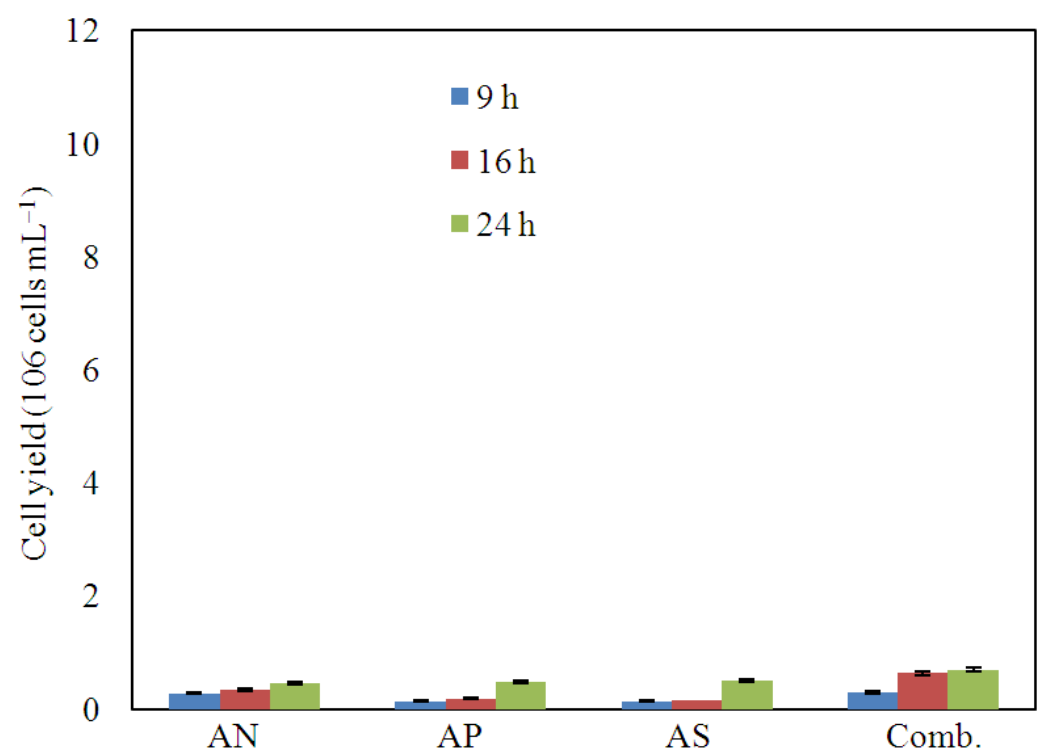

(a) Chlorella saccharophila

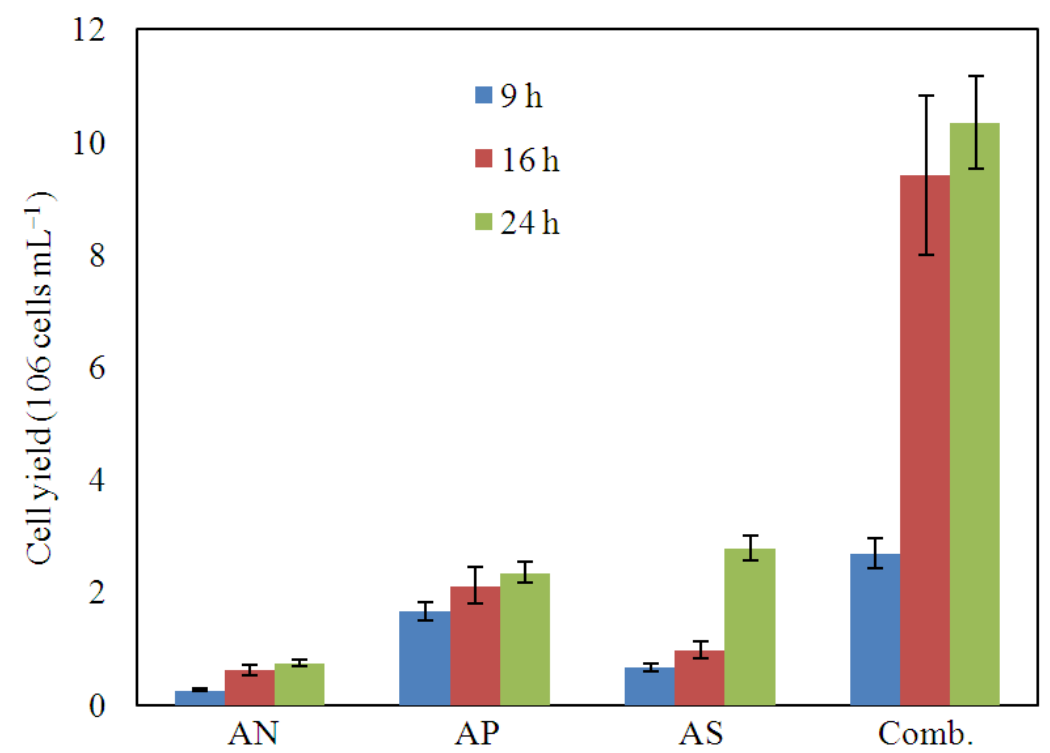

(b) Tetraselmis suecica

Fig. 9. Effect of nutrient type on the cell yield (cells/mL) of freshwater (Chlorella saccharophila) and marine (Tetraselmis suecica) microalgae at varying light durations (AN: Ammonium Nitrate, AP: Ammonium Phosphate, AS: Ammonium Sulfate, Comb: Combination of nutrients)

Table 11. Analysis of the variance for oil content

\begin{tabular}{|c|c|c|c|c|c|}
\hline Source & DF & $\mathrm{SS}$ & MS & $\mathrm{F}$ & $\mathrm{P}$ \\
\hline Total & 71 & 8296.85 & & & \\
\hline \multicolumn{6}{|l|}{ Model } \\
\hline Species (S) & 1 & 3866.82 & 3866.82 & 80.37 & 0.001 \\
\hline Nutrient $(\mathrm{N})$ & 3 & 765.33 & 255.11 & 5.30 & 0.003 \\
\hline Light (L) & 2 & 31.62 & 15.81 & 0.33 & 0.722 \\
\hline $\mathrm{S} * \mathrm{~N}$ & 3 & 895.03 & 298.34 & 6.20 & 0.001 \\
\hline $\mathrm{S} * \mathrm{~L}$ & 2 & 50.24 & 25.12 & 0.52 & 0.597 \\
\hline $\mathrm{N} * \mathrm{~L}$ & 6 & 210.31 & 35.05 & 0.73 & 0.629 \\
\hline $\mathrm{S} * \mathrm{~N} * \mathrm{~L}$ & 6 & 168.01 & 28.00 & 0.58 & 0.743 \\
\hline Error & 48 & 2309.49 & 48.11 & & \\
\hline
\end{tabular}

DF: Degree of Freedom; SS: Sum of Square; MS: Mean of Square; F: F Distribution; P: Probability-Value; ${ }^{2}=0.72 ; \mathrm{CV}=12.59 \%$ 
Table 12. Tukey's grouping for oil content

\begin{tabular}{lllcl}
\hline Factors & Level & $\mathrm{N}$ & Mean oil content (\%) & Tukey's grouping \\
\hline Species & Freshwater & 36 & 15.918 & $\mathrm{~B}$ \\
& Marine water & 36 & 1.261 & $\mathrm{~A}$ \\
Nutrient & Ammonium phosphate & 18 & 13.560 & $\mathrm{~A}$ \\
& Combination & 18 & 9.214 & $\mathrm{~A} \mathrm{~B}$ \\
& Ammonium nitrate & 18 & 6.730 & $\mathrm{~B}$ \\
Light (h) & Ammonium sulfate & 18 & 4.853 & $\mathrm{~B}$ \\
& 9 & 24 & 9.523 & $\mathrm{~A}$ \\
& 16 & 24 & 8.194 & $\mathrm{~A}$ \\
\end{tabular}

Groups with the same letter are not significantly different from each other at the alpha significance level of 0.05

Chlorella saccharophila. The nutrient types ammonium nitrate, ammonium sulfate and the combination of nutrients were not significantly different from one another, but were significantly different from the ammonium phosphate at the 0.05 level. However, the ammonium phosphate system was not significantly different from the combination of nutrient system. The highest mean oil yield of $13.56 \%$ was achieved using the ammonium phosphate system. The levels of light exposure were not significantly different from one another. The highest mean oil yield of $29.1 \%$ was achieved with the $9 \mathrm{~h}$ light duration.

\section{Effect of Microalgae Type}

The effect of microalgae type on the microalgae oil content is shown in Fig. 10. Chlorella saccharophila achieved the highest oil yields using all nutrient types at all light durations. It achieved in oil yields of 13.17, 29.08, 7.17 and $22.44 \%$ while Tetraselmis suecica achieved oil yields of $1.48,1.21,1.17$ and $0.45 \%$ at the 9 $\mathrm{h}$ light exposure using ammonium nitrate, ammonium phosphate, ammonium sulfate and combination of nutrients, respectively. Similar trends were observed at the other light exposures (16 and $24 \mathrm{~h}$ ).

The results showed that the oil yields obtained from Chlorella saccharophila were 10 fold higher than those obtained from Tetraselmis suecica, despite the higher biomass yields obtained from the Tetraselmis suecica species. This can be attributed to the use of energy as different species use their energy for different metabolic pathways (Pittman et al., 2011). Sharma et al. (2012) stated that the occurrence and extent to which lipids are produced by microalgae is species/strain specific. Chlorella saccharophila cells are better at accumulating lipids at the expense of cell division while the Tetraselmis suecica cells are better at cell division at the expense of storing lipids. Rodolfi et al. (2009) reported that higher biomass yields correspond to lower cellular lipid content and noted that Prophyridum cruentum, Scenedesmus, Chlorella and Chaetoceros calcitrans resulted in biomass productivities of $0.37,0.26,0.23$ and $0.04 \mathrm{~g} / \mathrm{L} / \mathrm{d}$ and lipid contents of $9.5,21.1,18.7$ and $39.8 \%$, respectively. Pai and Lai (2011) achieved a 9 fold increase in cell yield of the oleaginous algae (from $28.3 \mathrm{mg} / \mathrm{L}$ to $254 \mathrm{mg} / \mathrm{L})$, but the oil content only increased by 1.6 fold (from $20.4 \%$ to $33.6 \%$ ).

Several researchers (Herrera-Valencia et al., 2011; Isleten-Hosoglu et al., 2012; Chinnasamy et al., 2010; Tan and Johns, 1991) indicated that higher oil productivities were achieved using the Chlorella saccharophila (63.3-153 $\mathrm{mg} / \mathrm{L} / \mathrm{d})$ microalgae as opposed to Tetraselmis suecica (14.8-32 mg/L/d). Isleten-Hosoglu et al. (2012) reported a lipid content of 29.5\% from Chlorella saccharophila. Liu et al. (2011) reported a lipid content of $45 \%$ and a lipid productivity of $153 \mathrm{mg} / \mathrm{L} / \mathrm{d}$ for Chlorella saccharophila. Chinnasamy et al. (2010) reported a lipid content of $12.90 \%$ for Chlorella saccharophila. Tan and Johns (1991) reported a lipid content of $47 \%$ for Chlorella saccharophila. Danquah et al. (2010) reported a lipid yield of $108.7 \mathrm{mg} / \mathrm{L}$ for Tetraselmis suecica. Griffiths and Harrison (2009) reported a lipid productivity of 32 $\mathrm{mg} / \mathrm{L} / \mathrm{d}$ for Tetraselmis suecica. Montero et al. (2011) reported a lipid productivity of $27 \mathrm{mg} / \mathrm{L} / \mathrm{d}$ for microalga Tetraselmis suecica. Moheimani (2013) reported a lipid productivity of $14.8 \mathrm{mg} / \mathrm{L} / \mathrm{d}$ for Tetraselmis suecica. These values are higher than those obtained in this study. The differences can be attributed to the varying cultivation periods, variation in nutrient systems and the effectiveness in the oil extraction methods used.

\section{Effect of Light}

The effect of light duration on the oil content for Chlorella saccharophila and Tetraselmis suecica is shown in Fig. 11. Increases in the light exposure from 9 $\mathrm{h}$ to $24 \mathrm{~h}$ resulted in decreased oil yields for all nutrient systems for both algae species. Increasing the light duration increased the photosynthetic activity and this decreased the oil content, as the cells use energy for generation of new cells at the expense of lipid storage (Sharma et al., 2012). Khotimchenko and Yakovleva (2005) stated that increasing light periods stimulates the growth, fatty acid synthesis and the formation of membrane components (chloroplast). Bandarra et al. (2003) noted that a shorter light exposure period increased the oil content in Isochrysis galbana. 


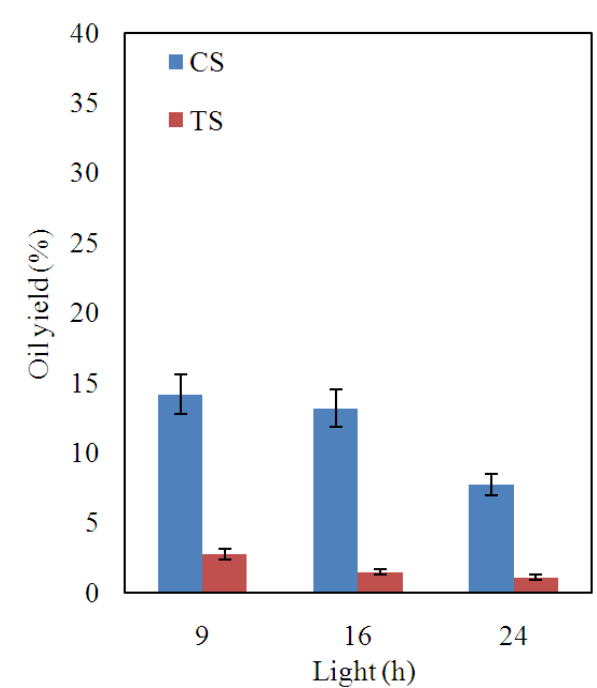

(a) Ammonium nitrate

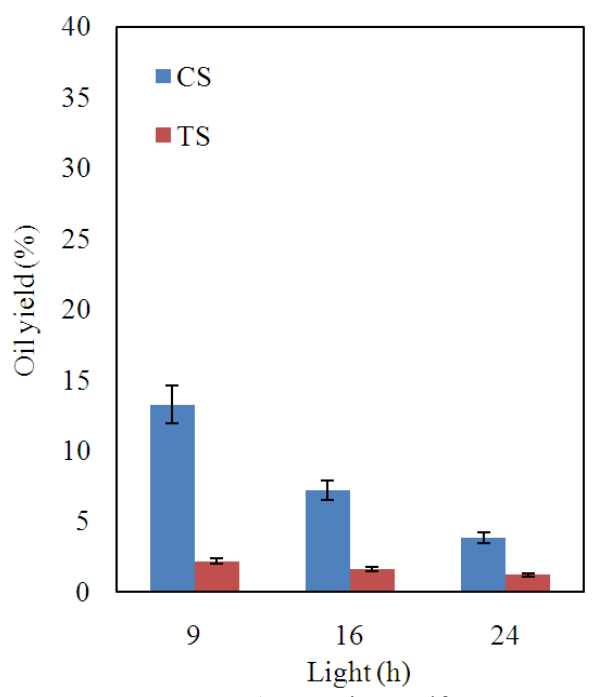

(c) Ammonium sulfate

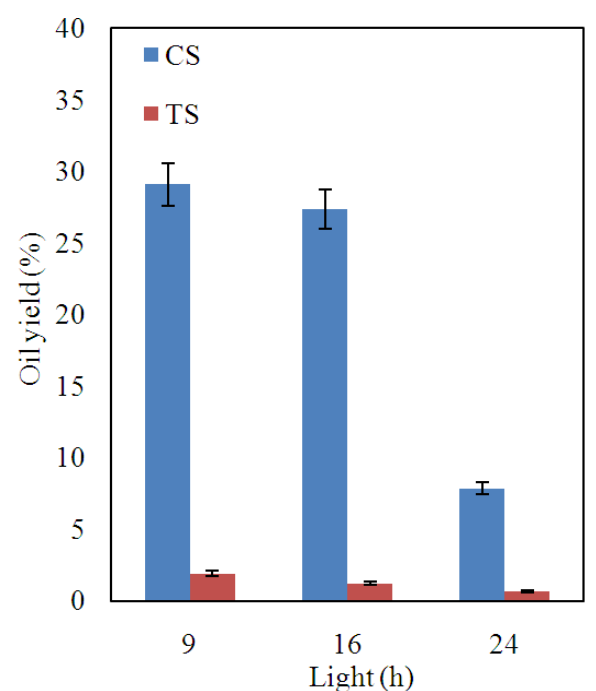

(b) Ammonium phosphate

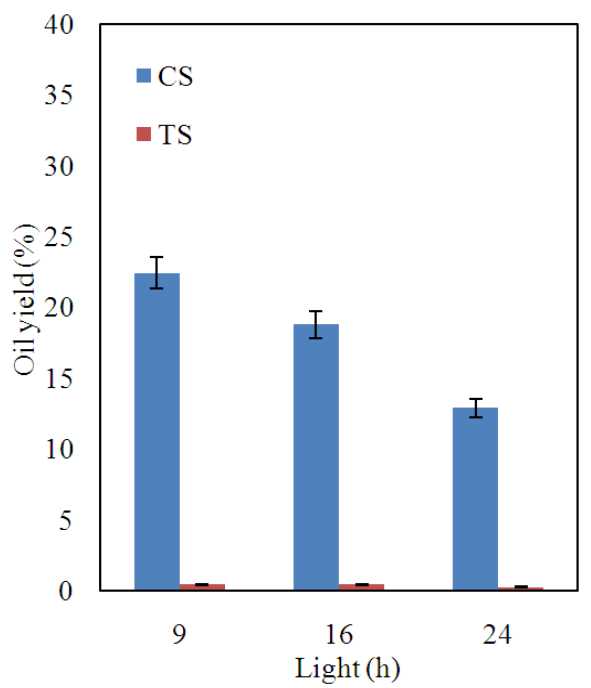

(d) Combination of nutrients

Fig. 10. Effect of microalgae type on the oil content (\%) using different nutrients and light exposures (CS: Chlorella saccharophila, TS: Tetraselmis suecica)

Wahidin et al. (2013) cultured marine microalgae Nannochloropsis sp. using a light intensity of 100 $\mu \mathrm{mol} / \mathrm{m}^{2} / \mathrm{s}$ at photoperiods of 18 and $24 \mathrm{~h}$ and found that the highest lipid content of $31.3 \%$ was achieved at the $18 \mathrm{~h}$ light exposure and an increase in light exposure to $24 \mathrm{~h}$ resulted in a lipid content of $27.9 \%$. Lim and Zaleha (2013) reported that the marine species Chaetoceros calcitrans, Chlorella sp. and Nannochlorosis had a higher lipid content at $12 \mathrm{~h}$ light exposure as opposed to $24 \mathrm{~h}$ light exposure. HerreraValencia et al. (2011) noted a lipid content of $40 \%$ for Chlorella saccharophila grown at $16 \mathrm{~h}$ light exposure. Perez-Pazos and Fernandez-Izquierdo (2011) achieved lipid yields Chlorella $s p$. of 0.25 and $0.17 \mathrm{~g} / \mathrm{L}$ at 6 and $18 \mathrm{~h}$ light exposures. These results are similar to those obtained in this study.

\section{Effect of Nutrient Type}

The effect of nutrient type on the oil content is shown in Fig. 12. Nutrient type plays an important role in oil yield. Ammonium nitrate, ammonium phosphate, ammonium sulfate and combination of nutrients resulted in oil content of 13.18, 7.71 and $14.16 \%, 29.08,27.35$ and $7.86 \%, 7.17,13.24$ and $3.78 \%$ and $22.44,12.91$ and $18.78 \%$ for Chlorella saccharophila and $1.48,1.10$ and $2.74 \%, 1.21,0.64$ and $1.88 \%, 1.18,2.16$ and $1.59 \%$ and $0.45,0.44$ and $0.27 \%$, for Tetraselmis suecica at the 9 , 16 and $24 \mathrm{~h}$, respectively.

In this study, the results indicate the highest oil content for the freshwater (Chlorella saccharophila) microalgae were achieved using ammonium phosphate nutrient as the addition of phosphorus stimulates the production and storage of lipids. This can also be seen 


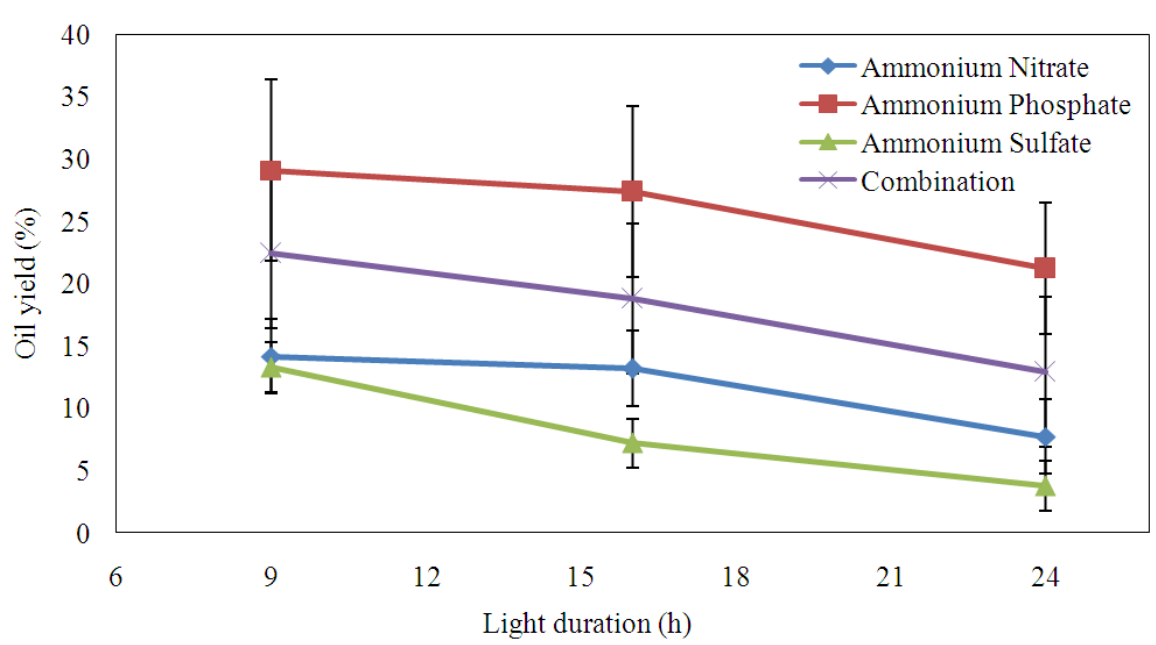

(a) Chlorella saccharophila

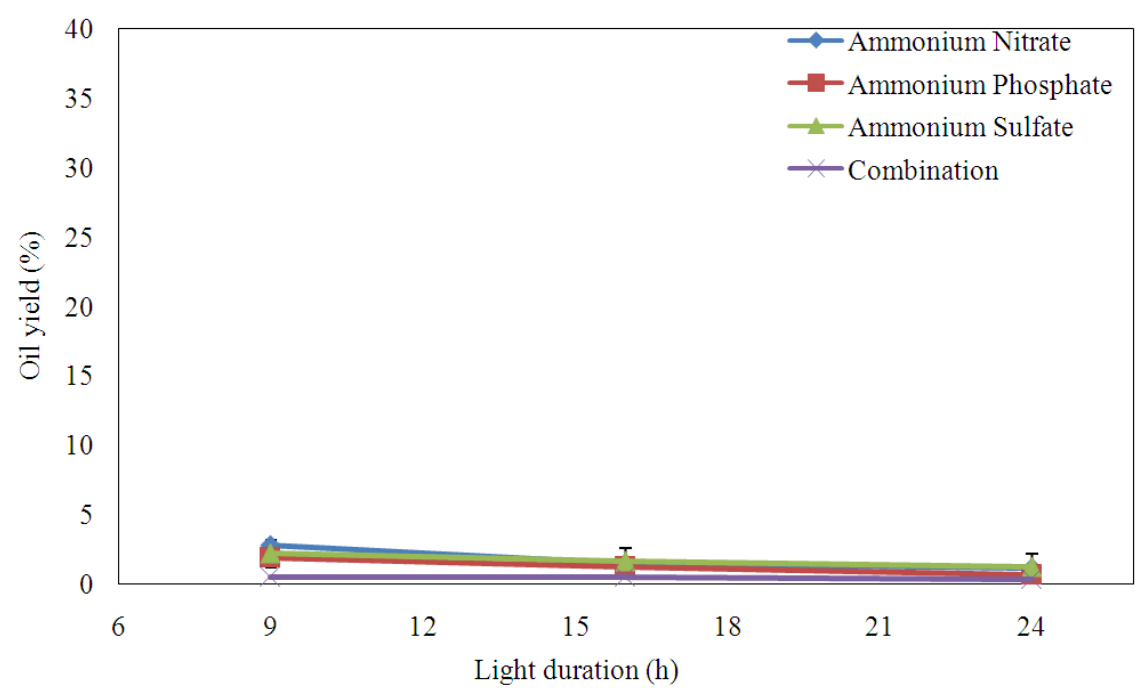

(b) Tetraselmis suecica

Fig. 11. Effect of light duration on the oil content of Chlorella saccharophila and Tetraselmis suecica at different nutrients and light durations

in the combination of nutrients system which resulted in the second highest oil content for this species, due to the presence of phosphorus. However, the difference between the two treatments was not significant. Similarly, the results for the marine microalgae Tetraselmis suecica indicate that the highest lipid content were achieved with the ammonium nitrate system and the lowest oil yields were achieved with the combination of nutrients (the opposite is true for biomass yields) which indicates that the medium with ammonium nitrate enhanced cell growth and the lack of sulfur and phosphorous caused the cells to store lipids instead of growth.

Kumar et al. (2012) noted increases in biomass (0.9$2.9 \mathrm{~g} \mathrm{~L}^{-1}$ ) and decreased lipid content (48-32\%) with increased concentrations of nitrogen. Converti et al. (2009) achieved an increase in lipid production upon nitrogen depletion for Nannochloropsis oculata and
Chlorella vulgaris. Mutlu et al. (2011) noted that Chlorella vulgaris increased lipid content from 12.29 to $35.6 \%$ when the culture was deprived of nitrogen but was phosphorus sufficient. Illman et al. (2000) reported a $40 \%$ increase in lipids in a low nitrogen containing medium. Reitan et al. (1994) reported that the microalgae Nannochloris atomus and Tetraselmis sp. had decreased lipid content due to phosphorous starvation. Sato et al. (2000) achieved an increase in lipid content with limitation of sulphur in Chlamydomonas reinhardtii. $\mathrm{Hu}$ et al. (2008) stated the sulfate limitation in microalgae promotes lipid accumulation.

\section{Conclusion}

The biomass and oil yields of Chlorella saccharophila (freshwater) and Tetraselmis suecica (marine) microalga were investigated using different 


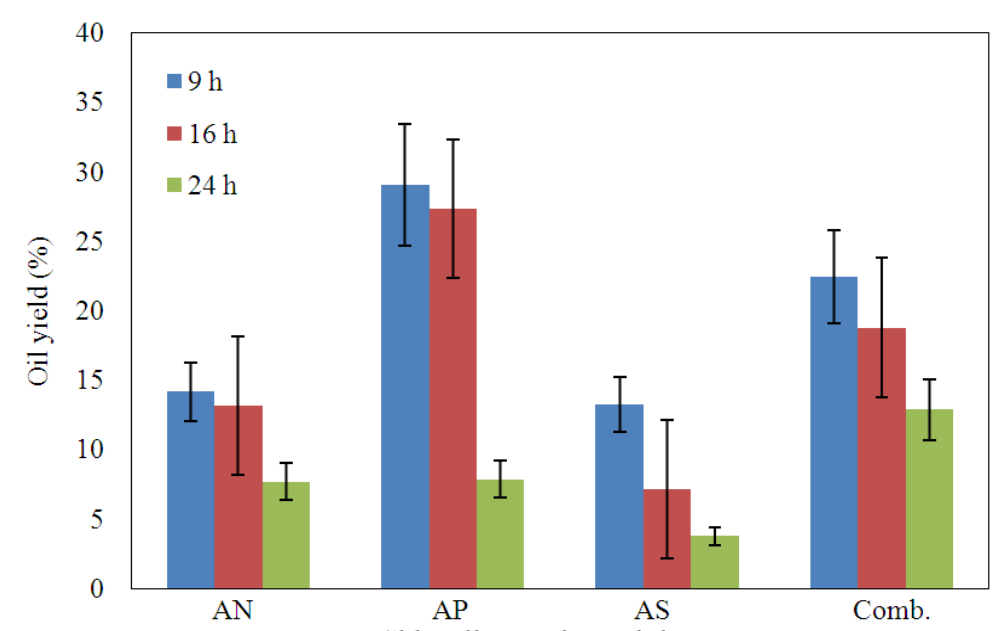

(a) Chlorella saccharophila

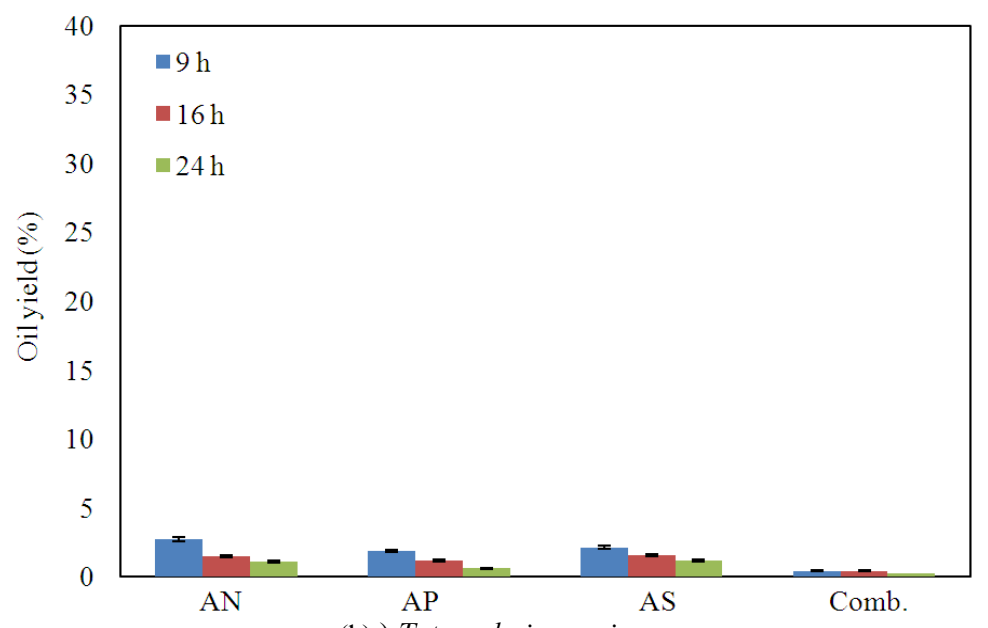

(b) ) Tetraselmis suecica

Fig. 12. Effect of nutrient type on the oil content of freshwater (Chlorella saccharophila) and marine (Tetraselmis suecica) microalgae at varying light durations. (AN: Ammonium nitrate, AP: Ammonium Phosphate, AS: Ammonium Sulfate, Comb: Combination of nutrients)

nitrogen sources (ammonium nitrate, ammonium phosphate, ammonium sulfate and combination of nutrients) at various light durations ( $9 \mathrm{~h}, 16 \mathrm{~h}$ and 24 h). $\mathrm{NaHCO}_{3}$ was used as the carbon source and the nitrogen, temperature and $\mathrm{pH}$ were maintained at 70 $\mathrm{mg} / \mathrm{L}, \quad 22^{\circ} \mathrm{C}$ and 8.5 , respectively. The results indicated that Tetraselmis suecica produced higher cell yields compared to the Chlorella saccharophila under all operating parameters. The biomass yields slightly increased with increasing light duration for both the Tetraselmis suecica and Chlorella saccharophila. However, there were no statistically significant differences between the light duration of 16 and $24 \mathrm{~h}$. The combination of nutrients resulted in the highest growth for both species of microalgae, but high growth did not necessarily result in high lipid yields. Both cell generation and lipid production require energy; when the cells use energy for production of new cells they produce less oil for storage. Higher oil yields were achieved with the freshwater (Chlorella saccharophila) microalgae compared to the marine (Tetraselmis suecica) microalgae. No significant differences between light durations on oil yield were noted. Chlorella saccharophila produced the highest lipid content (and lowest biomass yield) using ammonium phosphate nutrient while Tetraselmis suecica achieved the highest oil yields (and lowest cell yields) using ammonium nitrate. The combination of nutrients at $24 \mathrm{~h}$ light exposure resulted in the highest biomass yields for Chlorella saccharophila which resulted in the highest total lipid yield. However, the economics of increasing the light exposure period from 16 to $24 \mathrm{~h}(50 \%)$ is not offset by the slight increase in lipid yield (5\%).

\section{Acknowledgement}

This research was supported by the National Science and Engineering Council (NSERC) of Canada. 


\section{Author's Contributions}

The experimental work and data analysis were carried out by first author under the supervision of second author. The first draft was prepared by the first author and the review, correction and organization of the paper were made by second author.

\section{Ethics}

There are no ethical issues.

\section{References}

Abe, K., A. Imamaki and M. Hirano, 2002. Removal of nitrate, nitrite, ammonium and phosphate ions from water by the aerial microalga Trentepohila aurea. J. Applied Phycol., 14: 129-134.

DOI: $10.1023 / \mathrm{A}: 1019599216554$

Acuna, J.L. and M. Kiefer, 2000. Functional response of the appendicularian Oikopleura dioica. Limnol. Oceanography, 45: 608-618. DOI: $10.4319 /$ lo.2000.45.3.0608

Adams, E.E., 2013. Carbon emissions. Eco-Economy Indicators. Earth Policy Institute, Washington, DC.

Al-Qasmi, M., N. Raut, S. Talebi, A. Al-Rajhi and T. AlBarwani, 2012. A review of light on microalgae growth. Proceedings of the World Congress on Engineering, Jul. 4-6, London, U.K.

Araujo, G.S., L.J.B.L. Matos, J.O. Fernandes, S.J.M. Cartaxo and L.R.B. Goncalves et al., 2013. Extraction of lipids from microalgae by ultrasound application: Prospection of the optimal extraction method. Ultrason. Sonochem., 20: 95-98.

DOI: $10.1016 /$ j.ultsonch.2012.07.027

Areva, 2011. An energy demand in content increase. Areva Foundation.

Balat, H., 2009. Prospects of biofuels for a sustainable energy future: A critical assessment. Energy Educ. Sci. Technol. Part A, 24: 85-111. DOI: 10.1016/j.ijhydene.2010.04.137

Bandarra, N.M., P.A.Pereira, I. Batista and M.H. Vilela, 2003. Fatty acids, sterols and -tocopherol in Isochrysis galbana. J. Food Lipids, 18: 25-34. DOI: $10.1111 / \mathrm{j} .1745-4522.2003 . t b 00003 . x$

Barrientos, M. and C. Soria, 2011. World crude oil consumption by year. IndexMundi.

Becker, E.W., 1994. Microalgae: Biotechnology and Microbiology. 1st Edn., Cambridge University Press, Cambridge, ISBN-10: 0521350204, pp: 293.

Bock, C., L. Krienitz and T. Proschold, 2011. Taxonomic reassessment of the genus Chlorella (Trebouxiophyceae) using molecular signatures (barcodes), including description of seven new species. Fottea: J. Czech Psychol. Society, 11: 293-312.
Bondioli, P., L. Della Bella, G. Rivolta, G. Chini Zittelli and N. Bassi et al., 2012. Oil production by the marine microalgae Nannochloropsis sp. F\&M-M24 and Tetraselmis suecica F\&M-M33. Bioresourse Technol., 114: 567-672. DOI: 10.1016/j.biortech.2012.02.123

Chen, P., M. Min, Y. Chen, L. Wang and Y. Li et al., 2009. Review of the biological and engineering aspects of algae to fuels approach. Int. J. Agric. Biol. Eng., 2: 130. DOI: 10.3965/j.issn.1934-6344.2009.04.001-030

Chinnasamy, S., A. Bhatnagar, R.W. Hunt and K.C. Das, 2010. Microalgae cultivation in a wastewater dominated by carpet mill effluents for biofuel applications. Bioresourse Technol., 101: 3097-3105. DOI: 10.1016/j.biortech.2009.12.026

Chisti, Y., 2007. Biodiesel from microalgae. Biotechnol. Adv., 25: 294-306. DOI: $10.1016 /$ j.biotechadv.2007.02.001

Converti, A., A.A. Casazza, E.Y. Ortiz, P. Perego and M. Del Borghi, 2009. Effect of temperature and nitrogen concentration on the growth and lipid content of Nannochloropsis oculata and Chlorella vulgaris for biodiesel production. Chem. Eng. Process., 48: 1146-1151.

Costa, J.A.V., K.L. Cozza, L. Oliveira and G. Magagnin, 2001. Different nitrogen sources and growth responses of Spirulina platensis in microenvironments. World J. Microbiol. Biotechnol., 17: 439-442.

Danquah, M.K., R. Harun, R., R. Halim and G.M. Forde, 2010. Cultivation medium design via elemental balancing for Tetraselmis suecica. Chem. Biochem. Eng. Q., 24: 361-369.

De Castro Araujo, S. and V.M.T. Garcia, 2005. Growth and biochemical composition of the diatom Chaetoceros cf. wighmii brightwell under different temperature, salinity and carbon dioxide levels. I. Protein, carbohydrates and lipids. Aquaculture, 246: 405-412.

Demirbas, A. and M.F. Demirbas, 2011. Importance of algae oil as a source of biodiesel. Energy Convers. Manage., 52: 163-170.

DOI: 10.1016/j.enconman.2010.06.055

Demirbas, A., 2005. Biodiesel production form vegetable oils via catalytic and non-catalytic supercritical methanol transesterification methods. Progress Energy Combust. Sci., 31: 466-487. DOI: 10.1016/j.enconman.2005.11.019

Demirbas, A., 2010. Use of algae as biofuel sources. Energy Convers. Manage., 51: 2738-2749. DOI: 10.1016/j.enconman.2010.06.010

Demirbas, M.F., 2011. Biofuels from algae for sustainable development. Applied Energy, 88: 34733480. DOI: 10.1016/j.apenergy.2011.01.059

Demirbas, M.F., M. Balat and H. Balat, 2011. Biowastes-to-biofuels. Energy Convers. Manage., 52: 1815-1828. 
Epstein, P.R., 2000. Is global warming harmful to health? Scientific American, Inc.

Forcada, J., P.N. Trathan, K. Reid, E.J. Murphy and J.P. Croxall, 2006. Constrasting population changes in sympatric penguin species in association with climate warming. Global Change Biol., 12: 411-423. DOI: $10.1111 / \mathrm{j} .1365-2486.2006 .01108 . \mathrm{x}$

Fried, S., B. Mackie and E. Nothwehr, 2003. Nitrate and phosphate levels positively affect the growth of algae species found in Perry Pond. Grinnell College, Tillers, 4: 21-24.

Griffiths, M.J. and S.T.L. Harrison, 2009. Lipid productivity as a key characteristic for choosing algal species for biodiesel production. J. Applied Phycol., 21: 493-507.

Guillard, R.R.L. and J.H. Ryther, 1962. Studies of marine planktonic diatoms. I. Cyclotella nana Hustedt and Detonula confervaceae (Cleve) Gran. Canad. J. Microbiol., 8: 229-239. DOI: $10.1139 / \mathrm{m} 62-029$

Guzman-Murillo, M.A., C.C. Lopez-Bolanos, R. Ledesma-Verdejo, G. Roldan-Libenson and M.A. Cadena-Roa et al., 2007. Effects of fertilizer-based culture media on the production of exocellular polysaccharides and cellular superoxide dismutase by Phaeodactylum tricornutum (Bohlin). J. Applied Phycol., 19: 33-41.

Herrera-Valencia, V., P.Y. Contreras-Pool, S.J. LopezAdrain, S. Peraza-Echeverria and L.F. BarahonaPerez, 2011. The green microalga Chlorella saccharophila as a suitable source of oil for biodiesel production. Current Microbiol., 63: 151157. DOI: $10.1007 / \mathrm{s} 0028-011-9956-7$

Hessen, D.O., P.J. Faerovig and T. Andersen, 2002. Light, nutrients and $\mathrm{P}: \mathrm{C}$ ratios in algae: Grazer performance related to food quality and quantity. Ecology, 83: 1886-1898.

$\mathrm{Hu}$, Q., M. Sommerfeld, E. Jarvis, M. Ghirardi and M. Posewitz et al., 2008. Microalgal triacylglycerols as feedstocks for biofuel production: Perspectives and advances. Plant J., 54: 621-639.

Hughes, E.O., P.R. Gorham and A. Zehnder, 1959. Toxicity of a unialgal culture of microcystis aeruginosa. Canad. J. Microbiol., 4: 225-225. DOI: $10.1139 / \mathrm{m} 58-024$

Illman, A.M., A.H. Scragg and S.W. Shales, 2000. Increase in Chlorella strains calorific values when grown in low nitrogen medium. Enzyme Microbial Technol., 27: 631-635.

Isleten-Hosoglu, M., I. Gultepe and M. Elibol, 2012. Optimization of carbon and nitrogen sources for biomass and lipid production by Chlorella saccharophila under heterotrophic conditions and development of Nile red fluorescene based method for quantification of its neutral lipid content. Biochem. Eng. J., 61: 11-19. DOI: 10.1016/j.bej.2011.12.001
Ji, M.K., R.A.I. Abou-Shanab, S.H. Kim, E. Salama and S.H Lee et al., 2013. Cultivation of microalgae species in tertiary municipal wastewater supplemented with $\mathrm{CO}_{2}$ for nutrient removal and biomass production. Ecol. Eng., 58: 142-148.

John, D.M., 2002. The Freshwater Algal Flora of the British Isles: An Identification Guide to Freshwater and Terrestrial Algae. 1st Edn., Cambridge University Press, Cambridge, ISBN-10: 0521770513, pp: 702.

Juan, Y.Z., 2006. Growth and physiological responses of Chaetoceros mulleri and Dunaliella salina to different aquaculture wastewater. Nanjing Agricultural College, 1080441.

Kalam, M.A. and H.H. Masjuki, 2005. Recent developments on biodiesel in Malaysia. J. Scientific Industr. Res., 64: 920-927.

Kan, A., 2009. General characteristics of waste management: A review. Energy Educ. Sci. Technol. Part A, 23: 55-69.

Kaplan, D., A.E. Richmond, Z. Dubinsky and S. Aaronson, 1986. Algal nutrition. In: Crc Handbook of Microalgal Mass Culture, Richmond, A.E. (Ed.), CRC Press, Boca Raton, FL., ISBN-10: 0849332400.

Khoeyi, Z.A., J. Seyfabadi and Z. Ramezanpour, 2012. Effect of light intensity and photoperiod on biomass and fatty acid composition of the microalgae, Chlorella vulgaris. Aquaculture Int., 20: 41-49. DIO: $10.1007 /$ s10499-011-9440-1

Khotimchenko, S.V. and I.M. Yakovleva, 2005. Lipid composition of the red alga Tichocarpus crinitus exposed to different levels of photon irradiance. Phytochemistry, 66: 73-79.

DOI: 10.1016/j.phytochem.2004.10.024

Kumar, P., S.K. Shahi and P.K. Sharma, 2012. Effect of various cultural factors on isolated Spirulina strain for lipid and biomass accumulation. Current Discovery, 1: 13-18.

Larsdotter, K., 2006. Microalgae for phosphorus removal from wastewater in a Nordic climate. PhD Thesis, Royal Institute of Technology, Stockholm, Sweden.

Lavens, P. and P. Sorgeloos, 1996. Manual on the Production and Use of Live Food for Aquaculture. 1st Edn., FAO, Rome, ISBN-10: 9251039348, pp: 295.

Leung, D.Y.C., X. Wu and M.K.H. Leung, 2010. A review on biodiesel production using catalyzed transesterification. Applied Energy, 87: 1083-1095. DOI: $10.1016 /$ j.apenergy.2009.10.006

Lewis, L.A., 1997. Diversity and phylogenetic placement of Bracteacoccus Tereg (Chlorophyceae, Chlorophyta) based on 18S ribosomal RNA gene sequence data. J. Phycol., 33: 279-85. DOI: $10.1111 / \mathrm{j} .0022-3646.1997 .00279 . x$

Li, P., X. Miao, R. Li and J. Zhong, 2011. In situ biodiesel production form fast-growing and high oil content Chlorella pyrenoidosa in rice straw hydrolsate. J. Biomed. Biotechnol., 2011: 1-8. DOI: $10.1155 / 2011 / 141207$ 
Li, Y., M. Horsman, B. Wang, N. Wu and C.Q. Lan, 2008. Effects of nitrogen sources on cell growth and lipid accumulation of green alga Neochloris oleoabundans. Applied Microbiol. Biotechnol., 81: 629-636.

Lim, K.C. and K. Zaleha, 2013. Effect of photoperiod on the cellular fatty acid composition of three tropical marine microalgae. Malays. Applied Biol., 42: 41-49.

Liu, C.P. and L.P. Lin, 2001. Ultrastructural study and lipid formation of Isochysis sp. CCMP1324. Botanical Bull. Acad. Sinica, 42: 207-214.

Liu, J., J. Huang, Z. Sun, Y. Zhong and Y. Jiang et al., 2011. Differential lipid and fatty acid profiles of photoautotrophic and heterotrophic Chlorella zofingiensis: Assessment of algal oils for biodiesel production. Bioresource Technol., 102: 106-110. DOI: 10.1016/j.biortech.2010.06.017

Makareviciene, V., V. Andruleviciute, V. Skorupskaite and J. Kasperoviciene, 2011. Cultivation of microalgae Chlorella sp. and Scenedesmus sp. as a potential biofuel feedstock. Environ. Res. Eng. Manage., 3: 21-27.

Martinez, M.E., M. Jimenez and F. El Yousfi, 1999. Photoautrophic consumption of phosphorus by Scenedesmus obliquus in a continuous culture. Influence of light intensity. Process Biochem., 34: 811-818.

Mata, T.M., A.C. Melo, M. Simoes and N.S. Caetano, 2012. Parametric study of a brewery effluent treatment by microalgae Scenedesmus obliquus. Bioresource Technol., 107: 151-158.

DOI: 10.1016/j.biortech.2011.12.109

Matsuda, Y. and B. Colman, 1996. Active uptake of inorganic carbon by Chlorella saccharophila is not repressed by growth in high $\mathrm{CO}_{2}$. J. Exp. Botany, 47: 1951-1956. DOI: 10.1093/jxb/47.12.1951

Michels, M.H.A., P.M. Slegers, M.H. Vermue and R.H. Wijffels, 2013. Effect of biomass concentration on the productivity of Tetraselmis suecica in a pilot-scale tubular photobioreactor using natural sunlight. Algal Res.

DOI: $10.1016 /$ j.algal.2013.11.011

Moheimani, N.R., 2013. Inorganic carbon and $\mathrm{pH}$ effect on growth and lipid productivity of Tetraselmis suecica and Chlorella sp. (Chlorophyta) grown outdoors in bag photobioreactors. J. Applied Phycol., 25: 387-398.

Montero, M.F., M. Aristizabal and G.G. Reina, 2011. Isolation of high-lipid content strains of microalga Tetraselmis suecica for biodiesel production by flow cytometry and single-cell sorting. J. Applied Phycol., 23: 1053-1057. DOI: 10.1007/s10811-010-9623-6

Moronta, R., R. Mora and E. Morales, 2006. Response of the microalga Chlorella sorokiniana to $\mathrm{pH}$, salinity and temperature in axenic and non axenic conditions. Revista de la Facultad de Agronomia, 23: 27-41.
Mutlu, Y.B., O. Isik, L. Uslu, K. Koc and Y. Durmaz, 2011. The effects of nitrogen and phosphorus deficiencies and nitrite addition on the lipid content of Chlorella vulgaris (Chlorophyceae). African J. Biotechnol., 10: 453-456.

Odum, E.P., 1983. Basic Ecology. 1st Edn., Saunders College Publishing, Philadelphia, ISBN: 0-03-058414-0.

Okauchi, M. and M. Tokuda, 2003. Trophic value of the unicellular diatom Phaeodactylum tricornutum for larvae of Kuruma prawn, Penaeus japonicas. Proceedings of the 32nd UJNR Aquaculture Panel Meeting on Aquaculture and Pathobiology of Crustacean and Other Species, Nov. 16-22, Davis and Santa Barbara, CA.

Pai, T.Y. and W.J. Lai, 2011. Analyzing algae growth and oil production in a batch reactor under high nitrogen and phosphorus conditions. Int. J. Applied Sci. Eng., 9: 161-168.

Perez-Pazos, J.V. and P. Fernandez-Izquierdo, 2011. Synthesis of neutral lipids in Chlorella sp. under different light and carbonate conditions. Ciencia Technol. Futuro, 4: 47-58.

Pittman, J.K., A.P. Dean and O. Osundeko, 2011. The potential of sustainable algal biofuel production using wastewater resources. Bioresource Technol., 102: $17-25$.

Pokoo-Aikins, G., A.Nadim, M.E. El-Halwagi and V. Mahalec, 2010. Design and analysis of biodiesel production form algae grown through carbon sequestration. Clean Technol. Environ. Policy, 12: 239-254. DOI: 10.1007/s10098-009-0215-6

Reefsnow, 2012. Fitoplanction gen. Tetraselmis suecica. Reefsnow, Corso Martiri Patrioti, Italy.

Reitan, K.I., J.R. Rainuzzo and Y. Olsen, 1994. Effect of nutrient limitation on fatty acid and lipid content of marine microalgae. J. Phycol., 30: 972-979. DOI: $10.1111 /$ j.0022-3646.1994.00972.x

Rocha, J.M.S., J.E.C. Garcia and M.H.F. Henriques, 2003. Growth aspects of the marine mciroalga Nannochloropsis gaditana. Biomolecular Eng., 20: 237-424. DOI: 10.1016/S1389-0344(03)00061-3

Rodolfi, L., G.C. Zittelli, N. Bassi, G. Padovani and N. Biondi et al., 2009. Microalgae for oil: strain selection, induction of lipid synthesis and outdoor mass cultivation in a low-cost photobioreactor. Biotechnol. Bioeng., 102: 100-112. DOI: $10.1002 /$ bit.22033.

Root, T.L., J.T. Price, K.R. Hall, S.H. Schneider and C. Rosenzweig et al., 2003. Fingerprints of global warming on wild animals and plants. Nature, 421: 57-60.

Sato, N. and N. Murata, 1980. Temperature shift-induced responses in lipids in the blue green alga Anabaena variabilis: The central role of diacylmonalactosyglycerol in thermal adaptation. Biochimica Biophys. Acta, 619: 353-366. 
Sato, N., M. Hagio, H. Wada and M. Tsuzuki, 2000. Environmental Effects on Acidic Lipids of Thylakoid Membranes. In: Recent Advances in the Biochemistry of Plant Lipids, Harwood, J.L. and P.J. Quinn (Eds.), Portland Press Ltd, London, ISBN-10: 0387893660, pp: 912-914.

Sharma, K.K., H. Schuhmann and P.M. Schenk, 2012. High lipid induction in microalgae for biodiesel production. Energies, 5: 1532-1553.

Shi, X., Z. Wu and F. Chen, 2006. Kinetic modeling of lutein production by heterotrophic Chlorella at various $\mathrm{pH}$ and temperatures. Molecular Nutrit. Food Res., 50: 763-768. DOI: $10.1002 / \mathrm{mnfr} .200600037$

Singh, A., P.S. Nigam, J.D. Murphy, 2010. Mechanism and challenges in commercialisation of algal biofuels. Bioresource Technol., 102: 26-34. DOI: 10.1016/j.biortech.2010.06.057

Singh, D., M. Puri, S. Wilkens, A.S. Mathur and D.K. Tuli et al., 2013. Characterization of a new zeaxanthin producing strain of Chlorella saccharophila isolated from New Zealand marine waters. Bioresource Technol., 143: 308-314. DOI: 10.1016/j.biortech.2013.06.006

Singh, J. and S. Gu, 2010. Commercialization potential of microalgae for biofuels production. Renewable Sustainable Energy Rev., 14: 2596-2610. DOI: $10.1016 /$ j.rser.2010.06.014

Skaloud, P., 2007. H1986-Chlorella sorokiniana. Phycological Research Group, Charles University in Prague, Czech Republic.

Song, D., J. Fu and D. Shi, 2008. Exploitation of oilbearing microalgae for biodiesel. Chin. J. Biotechnol., 24: 341-348.

Spolaore, P., C. Joannis-Cassan, E. Duran and A. Isambert, 2006. Commercial applications of microalgae. J. Biosci. Bioeng., 101: 87-96. DOI: $10.1263 /$ jbb. 101.87

Tan, C.K. and M.R. Johns, 1991. Fatty acid production by heterotrophic Chlorella saccharophila. Hydrobiologia, 215: 13-19.

DOI: $10.1007 / \mathrm{BF} 00005896$
Thomas, W.H., D.L.R. Seibert, M. Alden, A. Neori and P. Eldridge, 1984. Yields, photosynthetic efficiencies and proximate composition of dense marine microalgal cultures. I. Introduction and Phaeo-dactylum tricornutum experiments. Biomass, 5: 181-209.

Totsche, O., A. Fyson and C.E.W. Steinberg, 2006. Microbial alkalinity production to prevent reacidification of neutralized mining lakes. Mine Water Environ., 25: 204-213.

Ulusoy, Y., Y. Tekin, M. Cetinkaya and F. Karaosmanoglu, 2004. The engine tests of biodiesel from used frying oil. Energy Sources, 26: 927-932. DOI: $10.1080 / 00908310490473219$

Velichkova, K., I. Sirakov and G. Georgiev, 2012. Cultivation of Botryococcus braunii strain in relation of its use for biodiesel production. J. Biosci. Biotechnol.

Wahidin, S., A. Idris and S.R.M. Shaleh, 2013. The influence of light intensity and photoperiod on the growth and lipid content of microalgae Nannochloropsis sp. Bioresource Technol., 129: 711. DOI: 10.1016/j.biortech.2012.11.032

Wahlen, B.D., R.M. Willis and L.C. Seefeldt, 2011. Biodiesel production by simultaneous extraction and conversion of total lipids form microalgae, cyanobacteria and wild mixed-cultures. Bioresource Technol., 102: 2724-2730.

DOI: 10.1016/j.biortech.2010.11.026

White, D.A., A. Pagarette, P. Rooks and S.T. Ali, 2012. The effect of sodium bicarbonate supplementation on growth and biochemical composition of marine microalgae cultures. J. Applied Phycol., 25: 153-165.

Yan, T., M. Zhou and P. Qian, 2002. Combined effects of temperature, irradiance and salinity on growth of diatom Skeletonema costatum. Chinese J. Oceanol. Limnol., 20: 237-243. DOI: 10.1007/BF02848852

Yenikaya, C., H. Yaman, N. Atar, Y. Eredogan and F. Colak, 2009. Biomass resources and decolorization of acidic dyes from aqueous solutions by biomass biosorption. Energy Educ. Sci. Technol. Part A, 24: 1-13. 